\title{
Combined with interventional therapy, immunotherapy can create a new outlook for tumor treatment
}

\author{
Tonglei Fang ${ }^{1 \#}$, Junyuan Xiao ${ }^{1 \#}$, Yiran Zhang ${ }^{1}$, Haiyan $\mathrm{Hu}^{2}$, Yueqi Zhu ${ }^{1}$, Yingsheng Cheng ${ }^{1}$ \\ ${ }^{1}$ Department of Radiology, Shanghai Jiao Tong University Affiliated Sixth People's Hospital, Shanghai, China; ${ }^{2}$ Department of Oncology, Shanghai \\ Jiao Tong University Affiliated Sixth People’s Hospital, Shanghai, China \\ "These authors contributed equally to this work.
}

Correspondence to: Yingsheng Cheng, MD; Yueqi Zhu, MD. No. 600, Yishan Road, Shanghai 200233, China. Email: chengyingsheng@hotmail.com; zhuyueqi@hotmail.com.

\begin{abstract}
Recent progress in immunotherapy provides hope of a complete cure to cancer patients. However, recent studies have reported that only a limited number of cancer patients with a specific immune status, known as "cold tumor", can benefit from a single immune agent. Although the combination of immune agents with different mechanisms can partially increase the low response rate and improve efficacy, it can also result in more side effects. Therefore, discovering therapies that can improve tumors' response rate to immunotherapy without increasing toxicity for patients is urgently needed. Tumor interventional therapy is promising. It mainly includes transcatheter arterial chemoembolization, ablation, radioactive particle internal irradiation, and photodynamic interventional therapy based on a luminal stent. Interventional therapy can directly kill tumor cells by targeted drug delivery in situ, thus reducing drug dosage and systemic toxicity like cytokine release syndrome. More importantly, interventional therapy can regulate the immune system through numerous mechanisms, making it a suitable choice for immunotherapy to combine with. In this review, we provide a brief description of immunotherapies (and their side effects) on tumors of different immune types and preliminarily elaborate on interventional therapy mechanisms to improve immune efficacy. We also discuss the progress and challenges of the combination of interventional therapy and immunotherapy.
\end{abstract}

Keywords: Immunotherapy; interventional therapy; tumor; immunomodulation

Submitted Jan 31, 2020. Accepted for publication Feb 01, 2021.

doi: 10.21037/qims-20-173

View this article at: http://dx.doi.org/10.21037/qims-20-173

\section{Method}

The Medline and EMBASE databases were searched using (at a minimum) the following keywords: tumor, immunotherapy, interventional therapy, and immunomodulation. All articles studying the immunomodulatory effect of interventional therapy and interventional therapy combined with immunotherapy for tumors were selected by examining their titles or abstracts. After further exploration of the content, articles containing relevant data were then included and summarized. According to the Grading of Recommendations
Assessment, Development, and Evaluation (GRADE) system, all selected articles were graded by their level of evidence and strength of recommendation. The literature searches were updated until October 2020.

\section{Introduction}

Cancer immunotherapy, which artificially stimulates the immune system and improves its natural ability to fight the disease, has long been seen as a hope to cure cancer. In recent years, with the prevalence of immunotherapy, 
especially immune checkpoint inhibitors (ICIs), immunotherapy has revolutionized cancer treatment. Cytotoxic T-lymphocyte-associated antigen 4 (CTLA-4) and programmed death 1 (PD-1) are the two most common checkpoint protein molecules in cancer immunotherapy. CTLA-4 (also named CD152) binds CD80 and CD86 with greater affinity and avidity than CD28, thus enabling the transmission of inhibitory signals into $\mathrm{T}$ cells. Ipilimumab is the first Food and Drug Administration (FDA)-approved CTLA-4 inhibitor and was initially used for melanoma treatment (1). Latest research has shown that ipilimumab can also work on non-small cell lung cancer (NSCLC), small cell lung cancer (SCLC), as well as bladder and prostate cancers $(2,3)$. Unlike the mechanism of CTLA-4 inhibitors, PD-1 inhibitors maintain the tumor cell inhibitory activity of effector $\mathrm{T}$ cells by inhibiting the binding of the PD-1 molecule on T cells to PD-L1 on tumor cells. Similar coinhibitory receptors include lymphocyte-activation gene 3 (LAG3), T cell immunoglobulin (Ig) and mucin domain 3 (TIM3), T cell immunoreceptor with Ig, and immunoreceptor tyrosinebased inhibition motif (ITIM) domains (TIGIT), etc. (4-7). Other passive immunotherapies include lymphocyte therapies [such as chimeric antigen receptor redirected $\mathrm{T}$ (CAR-T) cells], cytokine therapies [such as IFN- $\alpha$ and interleukin (IL)-2]. The first two FDA-approved CAR-T therapies, tisagenlecleucel and axicabtagene ciloleucel, target the CD19 antigen, which is found in many B-cell types of cancers. Cytokine therapy either directly promotes effector T cell function, for example, through IFN- $\alpha, \mathrm{IL}-2$, and IFN- $\gamma$, or promotes effector $\mathrm{T}$ cell infiltration locally in the tumor, such as through CXCL9, CXCL10, CXCL11, CCL2, and CCL5 $(8,9)$.

Active immunotherapies, such as tumor vaccines and oncolytic viruses (OVs), direct the immune system to attack tumor cells by targeting tumor antigens. Cancer vaccines trigger or amplify tumor antigens' presentation to either treat existing cancer or prevent the development of cancer. Sipuleucel- $T$ is a therapeutic cancer vaccine approved by the FDA for metastatic hormone-refractory prostate cancer. OVs are genetically engineered viruses that can selectively infect and replicate in tumor cells and ultimately resulting in tumor cell lysis and immunogenic death (10-16). Several viruses, including herpesviruses, poxviruses, picornaviruses, adenoviruses, paramyxoviruses, parvoviruses, reoviruses, Newcastle disease virus, and rhabdoviruses, have now been clinically tested as oncolytic agents (10). T-Vec is the first FDA-approved oncolytic virus to treat melanoma in patients with inoperable tumors (13). Some approved immune drugs developed for treating cancers of different organs are listed in Table 1.

However, insufficient responses to this innovative therapy have also been found in some cases $(17,18)$, which may be due to different cancers' differential immunophenotypes. A previous study has shown that compared to ipilimumab alone, nivolumab plus ipilimumab (anti-PD-1 plus antiCTLA-4) can lead to a higher 2-year overall survival (63.8\% vs. $53.6 \%$ ) for melanoma patients; however, it can also result in higher treatment-related grade 3-4 adverse events (54\% vs. 20\%) (19). To "warm" cold tumors and thereby increase the response rate while reducing or not increasing immunotoxicity, researchers have tried to combine immunotherapy with other interventions (20) (Table 2).

\section{Immunotherapies based on tumor biological properties}

Although immunotherapy, especially ICIs, has achieved great success in cancer treatment, insufficient responses to this innovative therapy were also found in some cases $(17,18)$, which may be due to the differential immunophenotypes of different cancers. According to a relatively standardized method of classifying tumor immunophenotypes based on the Immunoscore (21-23), tumors are primarily classified into the following four biological types: hot tumors, T cell-excluded tumors, immunosuppressed tumors, and cold tumors. Tumors of different types well match different immunotherapy strategies (21).

Hot tumors are characterized by high-density lymphocyte infiltration at both the tumor center (TC) and the invasive margin (IM) (21-23). However, infiltrating lymphocytes are depleted because of the imbalance of classical 2 pathways (4), which is caused by the overexpression of tumor cells at some checkpoints. Blocking or stimulating costimulatory receptors $(4,24)$ can correct this imbalance and reactivate $\mathrm{T}$ cells to restore antitumor immunity. A relatively higher density lymphocyte infiltration characterizes $\mathrm{T}$ cell-excluded tumors at the IM but almost no infiltration at the TC. It has been found that this might be attributable to the lack of signals like CXCL9, CXCL10, and CCL5, which recruit $\mathrm{T}$ cells into the TC $(8,9)$, or the formation of physical and biochemical barriers at the IM (25-27). Unlike excluded tumors, which prevent $\mathrm{T}$ cells from being recruited to the TC (28), immunosuppressed tumors are characterized by very low lymphocyte infiltration at both the TC and IM. 
Table 1 Approved immune agents

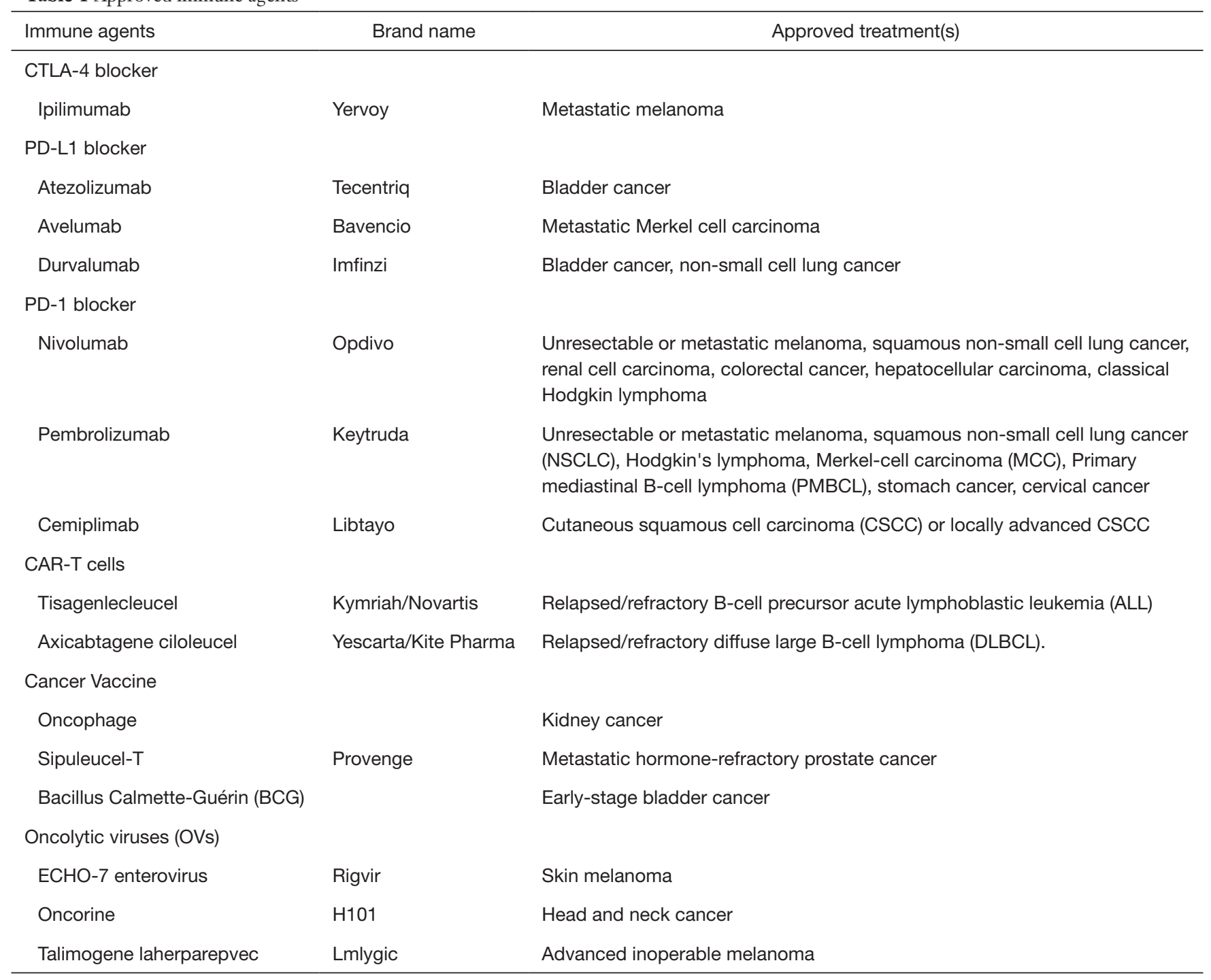

The main factors contributing to the formation of this immunosuppressive tumor microenvironment (TME) include soluble immunosuppressive factors like IL10 and TGF- $\beta(29,30)$ and inhibitory immune cells like type 2 macrophages (M2), myeloid-derived suppressor cells (MDSCs), and regulatory T cells (Tregs) (31-35). Integrating almost all of the above immunosuppression mechanisms into one, cold tumors are characterized by no lymphocyte infiltration at the TC or IM and are the most difficult tumor type to clear. To achieve clinical efficacy, it may be necessary to use combination therapy, that is, first enhancing the $T$ cell priming effect (via methods such as tumor vaccines, adoptive $T$ cell therapies, or therapies that can convert a tumor into a vaccine) to turn a cold tumor into a hot one and then combine with antibodies aimed at classic immune checkpoints. However, these combinations would increase immune-related adverse effects (IRAEs) and require rigorous monitoring during the entire process.

\section{Immune-related adverse effects (IRAEs) and limitations}

With their mechanism of action dependent on the physiological immobilization of inhibiting immune activation, ICIs usually have a miss target effect, which leads to immune-mediated inflammation of various organs or tissues (36-39). This can sometimes be serious, with up to $60 \%$ of grade $3-5$ adverse events occurring when anti- 
Table 2 Recruiting clinical trials of interventional therapy combined with immunotherapy

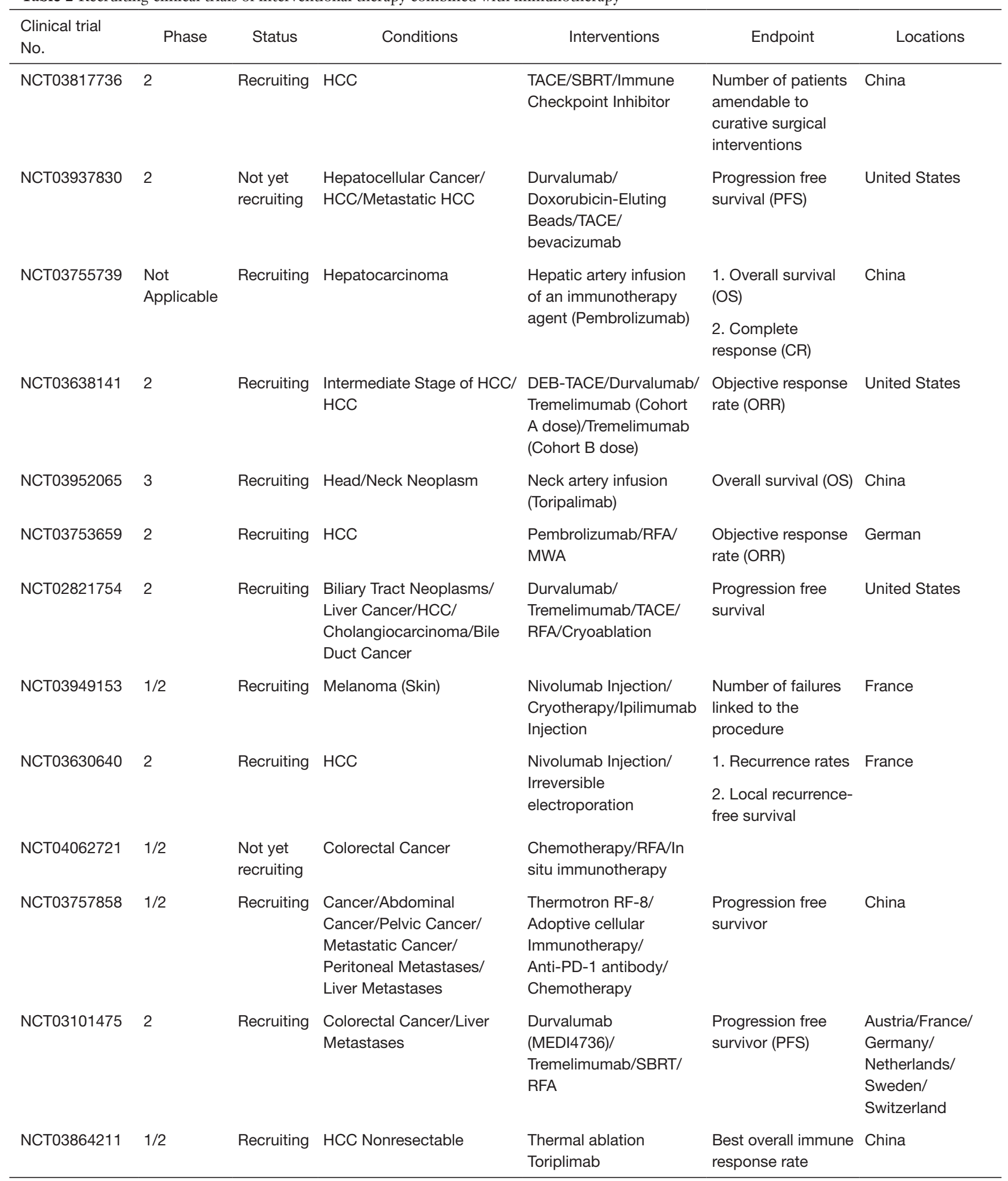

Table 2 (continued) 
Table 2 (continued)

\begin{tabular}{|c|c|c|c|c|c|c|}
\hline $\begin{array}{l}\text { Clinical trial } \\
\text { No. }\end{array}$ & Phase & Status & Conditions & Interventions & Endpoint & Locations \\
\hline NCT04049474 & 1 & $\begin{array}{l}\text { Not yet } \\
\text { recruiting }\end{array}$ & $\begin{array}{l}\text { Advanced Non-small Cell } \\
\text { Lung Cancer }\end{array}$ & $\begin{array}{l}\text { Cryo-Immunotherapy/ } \\
\text { Device: ERBOKRYO }{ }^{\circledR} \mathrm{CA} \\
\text { - Cryosurgical Unit with } \\
\text { Flexible ERBECRYO } \\
\text { Probe, } 1.9 \text { mm outer } \\
\text { diameter (ERBE, Inc., } \\
\text { Tubingen, Germany) }\end{array}$ & $\begin{array}{l}\text { 1. Number of } \\
\text { participants with } \\
\text { adverse events } \\
\text { 2. Overall response } \\
\text { rate }\end{array}$ & United States \\
\hline NCT04123535 & $\begin{array}{l}\text { Not } \\
\text { Applicable }\end{array}$ & $\begin{array}{l}\text { Not yet } \\
\text { recruiting }\end{array}$ & $\begin{array}{l}\text { Undifferentiated } \\
\text { Pleomorphic Sarcoma }\end{array}$ & $\begin{array}{l}\text { Device: ExAblate } \\
\text { 2000/2100 MRgFUS }\end{array}$ & $\begin{array}{l}\text { 1. Feasibility } \\
\text { 2. Safety }\end{array}$ & United States \\
\hline NCT03080974 & 2 & Recruiting & $\begin{array}{l}\text { Pancreatic } \\
\text { Adenocarcinoma }\end{array}$ & $\begin{array}{l}\text { Nivolumab/Irreversible } \\
\text { Electroporation }\end{array}$ & $\begin{array}{l}\text { Incidence of any } \\
\text { device-related } \\
\text { adverse events }\end{array}$ & United States \\
\hline NCT04108481 & $1 / 2$ & $\begin{array}{l}\text { Not yet } \\
\text { recruiting }\end{array}$ & $\begin{array}{l}\text { Colorectal Cancer } \\
\text { Metastatic/Colon Cancer/ } \\
\text { Metastatic Colorectal } \\
\text { Cancer/Rectal Cancer/ } \\
\text { Liver Metastasis Colon } \\
\text { Cancer/Colorectal } \\
\text { Cancer/Colorectal } \\
\text { Adenocarcinoma/ } \\
\text { Colorectal Neoplasms/Liver } \\
\text { Metastases/Colorectal } \\
\text { Carcinoma }\end{array}$ & $\begin{array}{l}\text { Durvalumab/Yttrium-90 } \\
\text { Radio Embolization }\end{array}$ & & United States \\
\hline NCT03812562 & 1 & Recruiting & $\mathrm{HCC}$ & $\begin{array}{l}\text { Nivolumab/Yttrium Y } \\
90 \text { Glass Microspheres }\end{array}$ & $\begin{array}{l}\text { Safety and } \\
\text { tolerability }\end{array}$ & United States \\
\hline NCT03945162 & 2 & Recruiting & NMIBC Refractory to BCG & $\begin{array}{l}\text { TLD-1433 Bladder } \\
\text { infusion and } \\
\text { Photodynamic Therapy }\end{array}$ & Recurrence rate & Canada \\
\hline NCT03727061 & 2 & Recruiting & $\begin{array}{l}\text { Recurrent Head and } \\
\text { Neck Carcinoma/Locally } \\
\text { Advanced Head and Neck } \\
\text { Carcinoma }\end{array}$ & $\begin{array}{l}\text { Nivolumab/ } \\
\text { Porfimer Sodium/ } \\
\text { Interstitial Illumination } \\
\text { Photodynamic Therapy/ } \\
\text { Pembrolizumab/ } \\
\text { Cisplatin/Carboplatin/ } \\
\text { Cetuximab/Fluorouracil }\end{array}$ & $\begin{array}{l}\text { Complete response } \\
\text { (CR) rate }\end{array}$ & United States \\
\hline
\end{tabular}

DEB-TACE, drug-eluting bead transcatheter; SBRT, stereotactic body radiation therapy; RFA, radio-frequency ablation; MWA, microwave ablation; MRgFUS, magnetic resonance-guided focused ultrasound; HCC, hepatocellular carcinoma; NMIBC, non-muscle invasive bladder cancer; BCG, bacillus calmette-guerin. 
CTLA-4 and anti-PD-1 are used simultaneously (40-42). Cytokine release syndromes (CRS) are common in patients treated with CAR-T cells. These complications are usually not life-threatening and can be controlled by administering steroids (43), adjusting dosage, or terminating the treatment if necessary. However, the regression of IRAEs caused by steroids can lead to steroid-related immunosuppression, which may also impair the antitumor response (39).

Current studies regarding CAR-T cell therapy have mainly focused on hematological cancer $(44,45)$, while studies regarding solid tumors are still in the early stages (46-51). Although cancer vaccines and oncolytic viruses seem harmless, they are mainly experimental and not extensively used in clinical practice as checkpoint inhibitors, and thus, the long-term toxicity remains unclear. CAR-T cells and vaccines are "autologous", meaning that the production of personalized CAR-T cells and tumor vaccines involves a high design cost and is time consuming. An OV's efficacy is primarily limited by the low effective bioavailability of the delivery route (52,53). At present, OVs are administered either through intratumoral injection, which greatly limits the scope of application or through intravenous injection, which also greatly weakens their efficacy due to the antiviral immune response.

\section{Interventional therapy and the combination with immunotherapy (Table 2, Figures 1,2)}

Due to the rapid development of interventional radiology, including transarterial chemoembolization (TACE), ablation, internal irradiation therapy, and photodynamic therapy (PDT), interventional therapy has become an important means of cancer treatment. Tumor interventional therapy has the advantages of small trauma, rapid recovery, targeting, and repeatability. It can be effectively combined with various modern medical methods and high-tech procedures to achieve a synergistic effect (54). More importantly, local cancer interventional therapy can regulate the immune system through different mechanisms, causing a systemic immune response $(21,55,56)$. Although this effect is too weak to prevent local recurrence or distant metastasis (55), it can expand the effectiveness of immunotherapy and might be a powerful combined strategy for immunotherapy. An ongoing phase II, single arm, multicenter study (NCT03469713) is attempting to analyze the objective response rate (ORR) of nivolumab plus stereotactic body radiotherapy (SBRT) in II and III lines of patients with metastatic renal cell carcinoma (mRCC), with the primary outcome measure being the frailty status as measured by the SHARE-frailty instrument measurement. This would be the first report on the safety profile of nivolumab in combination with SBRT.

\section{Transarterial chemoembolization (TACE)}

Due to the physiological basis of double blood supply in normal liver tissue and the fact that more than $95 \%$ of the blood supply of hepatocellular carcinoma (HCC) comes from the hepatic artery, TACE has mostly been applied to advanced unresectable HCC (57-59). It is aimed at killing tumor cells without causing severe adverse effects to normal hepatic tissue. TACE has also been employed as an alternative for resectable early stage HCC and in patients with regional recurrence of the tumor following previous resection and bridge therapy to surgery, radiofrequency ablation (RFA), or liver transplantation for downstaging (60-63). TACE has also demonstrated promising results in unresectable cholangiocarcinoma (64). Other treated malignancies include carcinoid tumors, pancreatic islet tumors, and sarcomas metastatic to the liver, whereas TACE's efficacy in patients with colorectal metastases is possibly palliative.

\section{Immunomodulatory effects of TACE}

It has been found that TACE can generate a bidirectional effect on tumor treatment by regulating the immune system. Embolization can lead to tumor tissue necrosis, thus reducing the mass and the release of immunosuppressive factors and weakening immune function inhibition (65). Moreover, necrotic tumor tissue can activate the systemic immune response by changing the phenotype of peripheral immune cells (66). Iodized oil-TACE increases infiltration of glypican 3 peptide-specific cytotoxic T lymphocytes. Embolization with polyvinyl alcohol (PVA) particles increases AFPspecific CD4+ T cells and is positively correlated with tumor necrosis and prognosis (67). On the other hand, embolization also reduces the number of peripheral $\mathrm{T}$ helper cells, which weakens the antitumor immune response (65). At the same time, embolization can induce a hypoxic microenvironment and upregulate the expression of vascular endothelial growth factor (VEGF), hypoxia inducible factor-1 (HIF-1), and PD-L1 on immune or tumor cells, resulting in an immunosuppressive effect (68).

\section{Application of TACE combined with immunotherapy}

The rational combination of TACE's bidirectional effect 


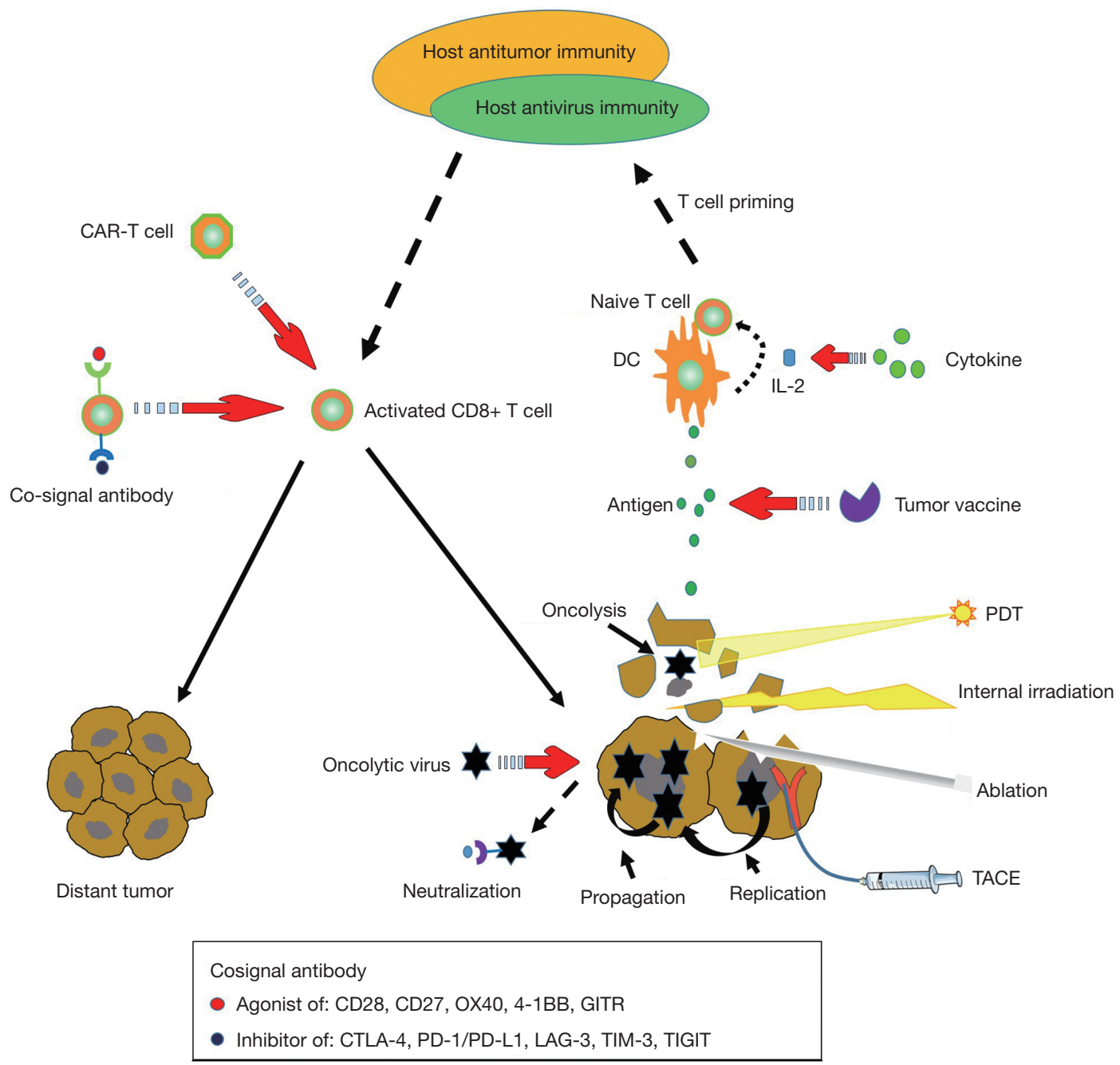

Figure 1 Immune mechanisms triggered by interventional therapies and potential immunotherapy category that could be applied together with interventional modalities. Interventional therapies, such as TACE, ablation, internal irradiation, and PDT, can cause immunogenic stress or death of tumor cells and produce a large number of tumor antigens. These processes can also induce strong inflammatory cell responses that promote DC maturation and increase the secretion of cytokines, such as chemokines, which drive the antigen presentation process. These specific antigens activate the maturation of immature $\mathrm{T}$ cells and promote their proliferation. Receptors on the surface of $\mathrm{T}$ cells can also bind to coinhibitory signals to inhibit the activation of T cells. As a foreign substance, OVs can also be recognized as foreign antigens. Antigenic "educated" T cells "patrol" throughout the body to seize those specific antigens, leading to the regression of distant tumors (or viruses). Immunotherapies such as OVs, tumor vaccines, CAR-T cells, nonspecific immunotherapy (cytokines such as CCLs, CXCLs), and cosignal antibodies (OX40, 4-1BB, anti-CTLA-4, anti-PD-1 etc.), can enhance the production of effector T cells and assist in killing tumor cells, and have a synergistic effect in combination with interventional therapies. TACE, transarterial chemoembolization; DC, dendritic cell; OVs, oncolytic viruses; CAR-T cells, chimeric antigen receptor redirected T cells.

on the immune system and immunotherapy is expected to achieve synergistic therapeutic effects (69). Duffy et al. (70) reported on a heavily pretreated post-sorafenib patient population with HCC who received two doses of tremelimumab followed by TACE. The result showed encouraging clinical activity, with $2 / 8$ patients achieving a partial response, as well as a median overall survival (OS) of 13.6 months [ $95 \%$ confidence interval (CI): 7.5 monthsundefined] and a median potential follow-up (from the study date until analysis) of 18.8 months. He et al. evaluated the 


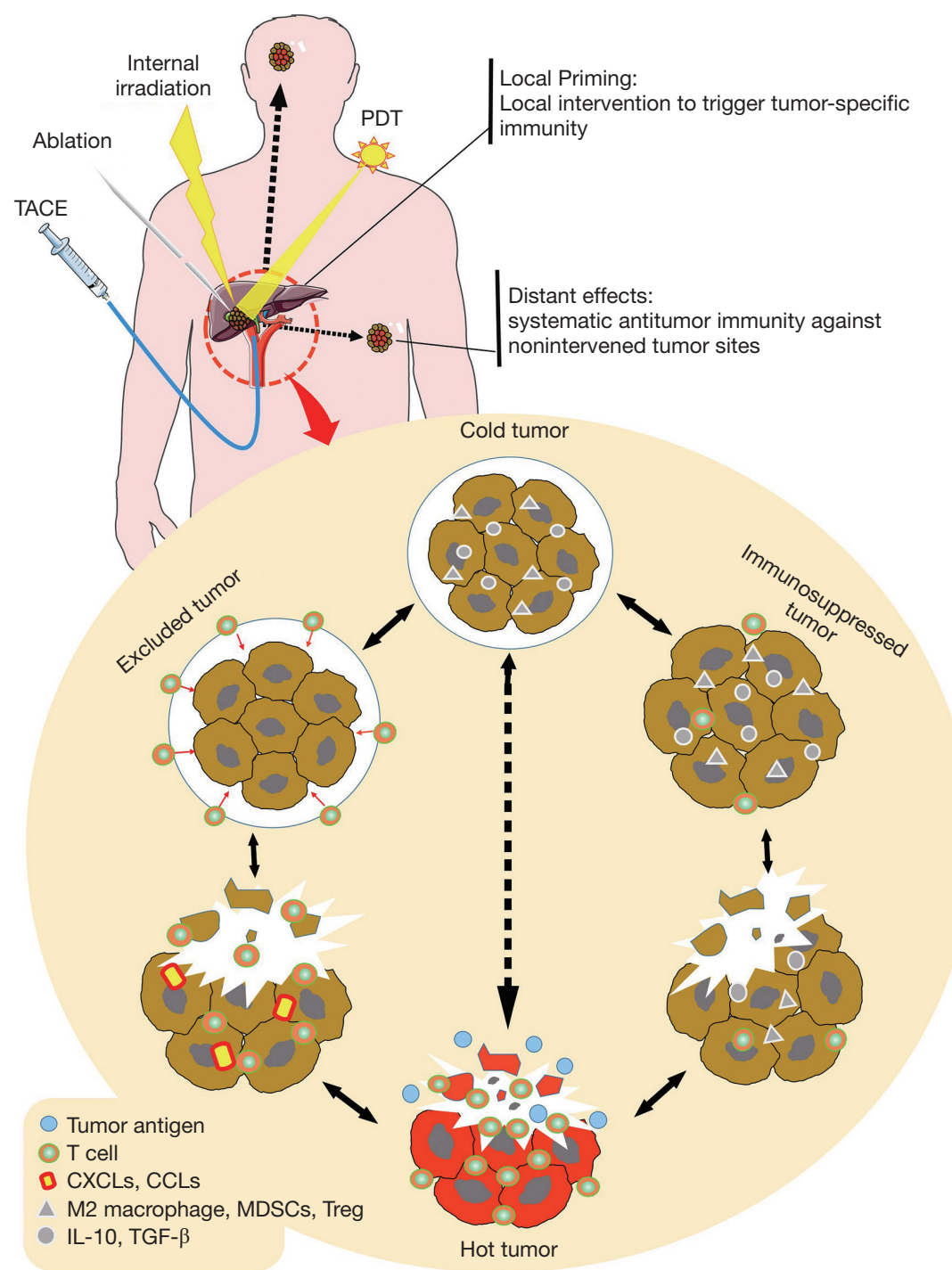

Figure 2 Immunomodulatory activity of interventional therapies on tumors with different immune status. Interventional therapy can transform tumors (such as cold tumors, excluded tumors, and immunosuppressed tumors) with no or low response to immunotherapies into hot tumors through a variety of mechanisms, including promoting immunogenic stress and death, forming an inflammatory environment, exposing antigens and reducing the tumor load, breaking physical and immunosuppressive biochemical barriers, etc. However, interventional therapies may also produce immunosuppressive factors such as IL-6, HIF-1 $\alpha$, HGF, and its receptor c-MET, which can upregulate the expression of PD-L1 and deepen the immunosuppressive state of tumors. IL-6, interleukin 6; HIF-1 $\alpha$, hypoxia-inducible factor 1 alpha; HGF, hepatocyte growth factor; PD-L1, programmed death-ligand 1.

efficacy of recombinant human type-5 adenovirus (H101) in patients with unresectable HCC treated by TACE (71). Compared with TACE monotherapy, patients treated with combined TACE and H101 therapy had increased OS rates $(61.0 \%, 40.0 \%$, and $31.5 \%$ vs. $55.0 \%, 33.4 \%$, and $22.3 \%$, for estimated 1-, 2-, and 3-year OS, respectively) and decreased cancer-specific mortality. Another case with recurrent HCC treated with a transarterial injection of H101 combined with TACE also led to a good clinical prognosis with no evidence of recurrence, no abnormal liver function, and a normal serum AFP level 18 months after the last H101/TACE treatment (72). Huang et al. tried to determine the clinical efficacy of sequential therapy with RFA and TACE compared to the autologous cytokine- 
induced killer (CIK) cell transfusion combined with RFA and TACE in the treatment of HCC. They found that the patients in the TACE + RFA + CIK group had a significantly longer OS (56 vs. 31 months, $\mathrm{P}=0.001$ ) and progressionfree survival (PFS) (17 vs. 10 months, $\mathrm{P}=0.001$ ) than those in the TACE+RFA group. They concluded that CIK cell immunotherapy might effectively prevent recurrence and metastasis in HCC patients after RFA and TACE (73).

Guo et al. studied patients with small-cell lung cancer and metastatic liver cancer who failed to achieve disease control after radiotherapy and chemotherapy and subsequently received TACE for liver metastasis and four courses of nivolumab-based immunotherapy. The results showed a sustained regression of hepatic and pulmonary lesions on imaging and a PFS of 15 months. The researchers concluded that TACE combined with nivolumab can enhance the antitumor immune responses and that there is a synergy between these two treatment modalities (74).

TACE's most frequently reported side effect is the selflimited post-embolization syndrome, which involves pain, fever, nausea, fatigue, and elevated transaminases (75). Other uncommon but serious complications include ischemic cholecystitis, pulmonary or cerebral embolization resulting from non-target embolization, and symptomatic hypothyroidism resulting from the contrast's high retained iodine load. Specialized techniques and devices may decrease the risk of adverse effects. In debilitated patients with advanced disease or impaired liver function, treatment-induced liver failure may offset the intervention's antitumoral effect or survival benefit. A prudent standard is required when selecting candidates for considering the possible complications of the procedure against its potential benefits.

In theory, TACE kills tumor cells via the following mechanisms: the embolic particles coated with chemotherapeutic drugs can not only interrupt the tumor blood supply and stall its growth but also locally and slow-release chemotherapy, allowing for the delivery of a higher dose in situ while simultaneously reducing systemic exposure (76). Meanwhile, less than half of large treated lesions demonstrate extensive necrosis in pathology (77), which might be a result of the upregulation of VEGF, HIF-1, and PD-L1 (78,79).

\section{Ablation}

Local ablative therapy has been applied for symptom palliating in patients with advanced tumors of the lung (80), kidney, bone (81), pancreas, and bile duct (82), as well as liver cancer with a small mass or at special sites where the tumor is directly abutting surrounding structures (such as the liver capsule, gallbladder, vessel, diaphragm, intestine, and adrenal gland), with a maximum distance of $1.0 \mathrm{~cm}$ between the tumor and these organs (83). It has also been utilized in the treatment of some benign lesions like osteoid osteomas (84-86), uterine fibroids, Morton's neuroma (87), skin lesions (88), and varicose veins. Furthermore, ablation has also been performed to treat precancerous lesions or oligo-progressive tumors. Numerous clinical trials have demonstrated that RFA is a safe and effective treatment for Barrett's esophagus, with more than $80 \%$ of patients achieving complete eradication after approximately two to three treatments (89-92). In patients with oligometastatic and oligoprogressive NSCLC, which is defined as those with limited metastatic disease, and in selected individuals with resistance to targeted therapies, evidence for the clinical benefit of local ablative therapy is increasing $(57,93)$. This includes RFA, microwave ablation (MWA), laser and high-intensity focused ultrasound (HIFU) ablation, irreversible electroporation (IRE), and cryoablation.

\section{Immunomodulatory effects of ablation}

Ablation can lead to local coagulation necrosis of tumors and can also improve the antitumor immune response through the following mechanisms:

(I) Increasing the exposure of tumor antigen: ablation leads to immunogenic death of the tumor and exposure of a large number of tumor antigens, allowing the tumor to act as an "in situ vaccine" $(93,94)$.

(II) Enhancing the immunogenicity of tumor antigens: heat shock proteins (HSPs) can act as carriers or peptide chaperones to bind to tumor antigens in order to form HSP complexes, which are presented by major histocompatibility complex (MHC) I molecules to activate CD4+/CD8+ T cells to induce specific cellular immunity against tumor cells. Ablation can increase HSP expression in tumor tissues and the periphery, thereby enhancing the immune response to HCC (95-97).

(III) Activating antigen-presenting cells (APCs) to increase tumor-specific $T$ cells: dendritic cells (DCs) are the most powerful APCs. When the local infiltration of DCs in tumors is insufficient or dysfunctional, which can lead to reduced cytokine release, the interaction of MHC-peptide complexes 
with $\mathrm{T}$ cell receptors does not lead to $\mathrm{T}$ cell expansion but rather to $\mathrm{T}$ cell tolerance $(98,99)$. Ablation can activate local DCs to proliferate and mature, and effector $\mathrm{T}$ lymphocytes to exert antitumor effects by presenting tumor antigens and releasing costimulatory signals and cytokines $(55,56)$.

(IV) Reducing immunosuppression: it has been found that ablation might reduce the release of immunosuppressive factors like $\mathrm{CD} 25^{+} \mathrm{Foxp}^{+}$ Tregs (55).

\section{Application of ablation combined with immunotherapy}

The immune response that is stimulated by energy-based ablations alone is often too modest to completely expunge established tumors (100). A clinical trial of the CTLA4 inhibitor tremelimumab combined with ablation in the treatment of advanced HCC (70) showed that, compared with tremelimumab alone, the combined therapy not only effectively controlled the lesions but also increased the accumulation of cytotoxic $\mathrm{T}$ cells in distant untreated lesions, increasing the objective response to immunotherapy. Bäcklund et al. reported a case of lung metastasis from colorectal cancer that remained uncontrolled after multiple surgical resections and stereotactic radiotherapy. After MWA combined with pembrolizumab, no new lung lesions or tumor recurrence were found during the 8-month follow-up (101). Three RFA cycles followed by the intravenous atezolizumab were performed in a case of recurrent squamous cell lung cancer in the left lower lobe after resection of the left upper lobe, as well as four cycles of adjuvant chemotherapy. The results showed that one lesion in the left lower lung that received RFA combined with atezolizumab displayed remarkable control, while another lesion in the right upper lung treated with the only atezolizumab showed little improvement (102). Another case reported by Soule et al. (103) showed that treatment of metastatic renal cell carcinoma (RCC) with percutaneous cryoablation and local administration of nivolumab could enhance the systemic immune response to metastatic bone lesions.

Studies in mouse models of prostate cancer (104) showed that local cryoablation of tumors did not affect distant secondary tumors' growth, whereas the combination with CTLA-4 inhibitors significantly slowed the growth and even eliminated secondary tumors. Compared with the cryoablation monotherapy group, the combination therapy group had more cytotoxic $\mathrm{T}$ cell infiltration in distant secondary tumors and a higher cytotoxic $\mathrm{T}$ cells ratio to Tregs. Similar results were also observed in melanoma (93) and colon cancer (105) models in mice. Qian et al. found that NOD scid gamma mice inoculated with the human melanoma WM115 cell line and then infused with chondroitin sulfate proteoglycan-4 (CSPG4)-specific CAR-T cells followed by photothermal ablation of the tumor showed more evidence of tumor decay, indicating that photothermal therapy facilitates the accumulation and effector function of CAR-T cells within solid tumors (106). Blanchard et al. found that direct cell ablation by stereotactic body radiation therapy (SABR) not only generated excellent control or cure of local, clinically detectable and accessible tumors but also induced relatively weak $\mathrm{T}$ cell responses, which could be boosted by systemically administered VSVTAA, contributing to the control of local and systemic disease (107). Zhao et al. treated a murine orthotopic pancreatic ductal adenocarcinoma model (KRAS* model) with irreversible electroporation and anti-PD1 and found that the combined therapy significantly prolonged the survival of the model and achieved a cure rate of $36-43 \%$ with a memory $\mathrm{T}$ cell response. The combined therapy also promoted tumor infiltration by CD8+ cytotoxic T cells without recruiting other immunosuppressive cells (108).

However, to date, due to the lack of high-level evidencebased medicine and prospective clinical studies with the multicenter, large sample, and randomized control, ablation therapies are only used as an alternative or complementary treatment in solid tumors except for some primary small liver cancers. Also, the therapeutic and side effects vary between different ablation equipment. Ablation can also promote the growth and metastasis of distant tumors by promoting the production of IL- 6 , HIF- $1 \alpha$, hepatocyte growth factor (HGF), and its receptor c-MET (109-111). These factors can upregulate the expression of PD-L1 $(112,113)$, thereby inhibiting the antitumor immunity effect of ablation.

\section{Internal irradiation therapy}

Radioisotopes are implanted into or adjacent to a tumor by interventional means, such as particle scaffolding or stents, to treat the tumor locally. This technique is now widely used to treat various malignancies; for example, iodine- 125 seed implantation in prostate cancer, radioembolization of HCC [Yttrium-90 (Y-90)-labeled microspheres], and iodine-125 particle-loaded radioactive stents for malignant tumors of the biliary tract or esophagus and for airway 
obstruction. Different studies have suggested that the effect of radioactive particle implantation is comparable to that of surgery and external radiotherapy and is superior to that of surgery when combined with other modalities $(114,115)$.

\section{Immunomodulatory effects of internal radiation therapy}

There are currently no direct studies demonstrating the effects of internal radiation therapy on the immune system. The traditional perception is that radiation exposure suppresses immunity; however, studies on external radiation therapy have shown that in some cases, radiotherapy with moderate radiation exposure can activate the immune system and enhance antitumor effects (21,116-120). Radiotherapy can destroy the irradiated tumor and control distant metastasis beyond the local treatment site, known as the "abscopal effect" of radiation therapy (121-123). The possible mechanisms of the activation of the antitumor immune response by radiation therapy are briefly summarized as follows:

(I) Increasing the exposure of tumor antigen: radiotherapy causes immunogenic death of tumor cells, which induces the release of tumor-associated antigens (TAAs), thus increasing the probability of tumor cells being recognized by $\mathrm{T}$ cells.

(II) Promoting the activation and maturation of DCs: radiotherapy induces immunogenic stress or death of tumor cells, leading to the release of dangerassociated molecular patterns (DAMPs) in the TME. DAMPs can bind relevant receptors (124-129) to promote the recruitment, phagocytosis, and migration of DCs, as well as induce the secretion of relevant cytokines by DCs, ultimately presenting tumor antigens to $\mathrm{T}$ cells to activate and stimulate the proliferation of $\mathrm{T}$ cells (130). The activated effector $\mathrm{T}$ cells can enter the circulation to capture tumor antigens, leading to regression of distant tumors (131,132).

(III) Promoting an inflammatory microenvironment: radiotherapy increases the expression of proinflammatory cytokines $(133-138)$ [such as IL$1 \beta$, TGF- $\beta$, FGF, and TNF, as well as the NACHT, LRR, and PYD domain-containing protein 3 (NALP3) inflammasome] and chemokines (such as CXCL9, CXCL10, CXCL11, and CXCL16), which in turn recruit immune cells into the TME. However, the recruited immune cells can be either antitumor immune cells, such as DCs and effector T cells $(139,140)$, or tumor-promoting immune cells, such as Tregs, MDSCs, and tumorassociated macrophages (TAMs) (132,141-145). Also, radiotherapy converts tumor-associated macrophages into type 1 macrophages (M1) and increases the expression of the tumor endothelial cell adhesion molecules Icam-1 and Vcam-1, which facilitate the recruitment of $T$ cells to tumors (146). Radiotherapy also upregulates the IFN- $\gamma$-mediated expression of PD-L1 on the surface of tumor cells (143).

(IV) In addition to the direct stimulation of the adaptive immune system, deoxyribonucleic acid (DNA) released from the cell injury mediated by radiotherapy can activate and promote the production of interferon type 1 (IFN-1) through Toll-like receptors, RIG-1-like receptors, and stimulator of interferon gene (STING), improving the antitumor immune response mediated by $\mathrm{T}$ cells. However, this process requires the infiltration of $\mathrm{CD}_{103^{+}}$DCs into the tumor so that the efficacy could be limited in tumors barren of T cells while being effective in T cell "excluded" tumors $(142,143)$.

\section{Application of internal irradiation combined with immunotherapy}

Conventional and simple radiotherapy upregulates the expression of PD-L1 on the surface of tumor cells mediated by IFN- $\gamma$ and is considered to be one of the most important factors in tumor resistance to radiotherapy $(143,147)$. Studies $(143,148)$ have shown that after conventional radiotherapy in melanoma, colorectal cancer, and triplenegative breast cancer models in mice, the expression of PD-L1 on tumor cells increased, resulting in resistance to radiotherapy. However, radiotherapy combined with PD-1/PD-L1 inhibitors enhances antitumor-specific $T$ cell immune responses and reduces the number of MDSCs in the TME to improve radiotherapy's therapeutic efficacy. Confino et al. found that Da3 mice with breast cancer and lung metastasis treated with a combination of DaRT wires in combination with an MDSC inhibitor (sildenafil), Treg inhibitor (cyclophosphamide at low dose), and the immunostimulant, $\mathrm{CpG}, 3 / 20$ showed complete rejection with primary tumors and elimination with lung metastases. The other mice treated with different strategies also showed a reduced tumor burden and prolonged survival compared to the controls' corresponding outcomes (149).

Kwon et al. conducted a multicenter randomized double-blind phase III clinical trial to assess the clinical 
efficacy of radiotherapy combined with ipilimumab after chemoresistance in castration-resistant prostate cancer but concluded no significant difference between the groups in terms of OS in the primary analysis (11.2 vs. 10.0 months; $\mathrm{P}=0.05$ ) (150). In another phase, I clinical trial, 22 patients with metastatic melanoma were treated with a combination of radiotherapy and ipilimumab. The analysis showed that $18 \%$ of patients had a partial response, $18 \%$ were stable, and $64 \%$ continued to progress after refusing combination therapy. Furthermore, it was also found that radiotherapy combined with two ICIs with different mechanisms (a CTLA-4 inhibitor and a PD-1/PD-L1 inhibitor) significantly increased the complete response rate of mice with melanoma (151). A phase 2 multicenter trial to determine if combined treatment with PSA/TRICOM vaccine and $153 \mathrm{Sm}$-EDTMP radiation could delay the progression of prostate cancer better than radiation alone showed no significant difference in the primary endpoint and the median PFS (3.7 vs. 1.7 months) ( $\mathrm{P}=0.041, \mathrm{HR}=0.51$, $\mathrm{P}=0.046) ; 3 / 21$ patients in the combination arm achieved PSA decline $>50 \%$, compared with no patients in the Sm153-EDTMP alone arm >30\% (152).

Radioembolization is a minimally invasive technique that combines embolization and internal radiation therapy, in which microspheres containing the radioisotope Y-90 are implanted into the tumor-feeding arteries, resulting in a high dose of radiation to the tumor and blockage of its blood supply. An open-label fixed-dose phase $\mathrm{Ib}$ trial (NCT02416466) of CAR-T hepatic artery infusions followed by selective internal radiation therapy (SIRT) with Y-90 Sir-Spheres ${ }^{\circledR}$ for CEA-expressing liver metastases has been completed; however, the results have not yet been published. Delivered via the vascular pathway, embolic microspheres can also cause non-target embolization, which could be avoided by taking appropriate measures before administering irradiation particles during the mapping procedure. Post radioembolization syndrome, which involves symptoms such as fever, fatigue, nausea, vomiting, and anorexia, is self-limited and only requires symptomatic management in some patients. However, this therapy may lead to cumulative radiation adverse effects on the medical staff who have been engaged in this work for an extended period.

\section{Photodynamic therapy (PDT)}

PDT was first proposed more than 100 years ago (153) and has since been intermittently used in the study of cancer treatment $(154,155)$. Photosensitizers (PSs), which act as catalysts, can convert molecular oxygen into a series of highly reactive oxygen species (ROS) under visible light exposure. This can kill tumor cells (156-158) via mechanisms such as direct necrosis or promotion of apoptosis to inhibit tumors (159), or cause changes in the tumor vasculature, such as the closure of blood vessels, thus hindering the supply of oxygen and nutrients to tumors $(160,161)$. PDT is highly effective for actinic keratosis of the skin, which could become cancerous, such as non-hyperkeratotic actinic keratosis on the face and scalp $(162,163)$ and actinic cheilitis on the lip (163). PDT has also shown promising efficacy in the treatment of superficial non-melanoma skin cancers (Bowen's disease) $(164,165)$, small uncomplicated superficial basal cell carcinoma (BCC), nodular BCC (162), and some other benign skin conditions (166).

\section{Immunoregulation of PDT}

PDT also has a significant effect on the immune system (167-169): (I) PDT can produce acute inflammation and attract leukocytes to the treated TME; (II) PDT can increase the immunogenicity of dead tumor cells by exposing or producing new antigens and increase the efficiency of antigen cross-presentation by inducing HSPs to form more effective tumor-specific cytotoxic T cells (158); (III) the proinflammatory effect of PDT may also increase DC migration, antigen uptake, and secretion of cytokines; and (IV) PDT can produce long-lasting tumor-specific immune memory.

\section{Application of photodynamic therapy combined with immunotherapy}

In a bilateral murine 4T1 breast cancer model, photodynamic therapy was used to intervene on one side of the tumors and was combined with a PD-L1 antibody's systemic administration. The results showed that combined therapy effectively killed the local tumor directly after exposure to light and significantly prevented distant metastasis, and even reduced the size of the existing tumors on the opposite side $(170,171)$. Also, cytotoxic T-lymphocyte (CTL) infiltration was significantly increased in distal tumors unexposed to light in the combination treatment group. The CTL infiltration levels in the control groups were not significantly affected, indicating that photodynamic therapy can reverse the immunosuppressive microenvironment within tumors and trigger CTL-mediated antitumor immunity. Ou et al. (172) used photodynamic therapy combined with imatinib to treat melanoma in mice (C57BL/6 mice) and found that 
photothermal and photodynamic effects could directly lead to tumor cell apoptosis, necrosis, production of TAAs, and maturation of DCs, which enhanced the presentation of TAAs to T cells. Also, imatinib-loaded GITR-PLGA reduced the suppressive function of Tregs, thereby activating CD8+ T cells. Gil et al. treated subcutaneously implanted syngeneic murine NXS2 neuroblastoma and human $\mathrm{FaDu}$ head and neck squamous cell carcinoma xenografts in nude mice with PDT and oncolytic vaccinia virus (OVV). They found that combination therapy could effectively inhibit the growth of primary and metastatic tumors compared with either monotherapy. Moreover, PDT-induced vascular disruption made the OVV-EGFP infection easier and resulted in higher intratumoral viral titers than those of the untreated tumors (173).

PDT has a good immunomodulatory effect and may induce positive therapeutic effects for malignant obstruction of the digestive tract and ureter or other superficial tumors. However, a meta-review (174) demonstrated a markedly higher average recurrence rate for squamous cell carcinomas treated with PDT (26.4\%) than other modalities, including standard surgical excision (5.4\%), cryotherapy (0.8\%), curettage and electrodessication (1.7\%), Mohs (3.0\%), and radiation $(6.4 \%)$. Therefore, they concluded that PDT indications should exclude lesions over $2 \mathrm{~cm}$, polymorphic lesions where biopsy may not represent the true histologic sample, and any lesions with dermoscopic characteristics of invasive SCC. Also, other disadvantages, including the time commitment (3-hour incubation period) and pain, are often outweighed when patients have multiple superficial BCCs, Gorlin syndrome, propensity for hypertrophic scarring, as well as a diseased lumen with malignant stenosis.

\section{Future challenges and opportunities}

The combination of interventional therapy and immunotherapy has presented new opportunities in the field of tumor research and treatment and has broad application prospects (Table 2). However, numerous relevant studies are still in their infancy, and many key questions need to be addressed.

Firstly, the dose and frequency of combination therapy need to be determined: (I) Dose and frequency of immunologic preparations: the dose and frequency schemes of immune agents currently used in most combination therapies are based on previous experience in clinical trials and need to be evaluated and adjusted during use. Moreover, no consensus has been reached. Considering the immunomodulatory effects and the local drug delivery function of interventional therapy and the aim of minimizing the immunotoxic side effects, the dose of immune agents is bound to decrease. (II) Amount and frequency of interventional therapy: some interventional therapies, such as ablation and internal irradiation therapy, can promote immunoreactivity and produce immunosuppressive effects. Shi et al. reported that inflammation induced by incomplete RFA could accelerate tumor progression and hinder PD-1 immunotherapy (175), suggesting that different effects may be related to the dose (range and length) of intervention. Also, the immunomodulatory effects of interventional therapy, such as the "thermalization" of cold tumors, may be transient (176), and thus, whether "thermalization" should be performed regularly needs to be further confirmed by relevant studies.

Secondly, the optimal timing and sequencing of immunotherapy and interventional therapy need to be determined. As previously mentioned, interventional therapy can lead to the release of tumor antigens through a series of mechanisms. Therefore, in theory, simultaneous intervention or intervention followed by immunotherapy, rather than the other way around, can better incite combination therapy's synergistic effects. Therefore, current studies regarding combination treatment with TACE and immunotherapy are designed to administer immunological agents either during or after TACE. Meanwhile, considering the lower median OS and common deterioration of the liver function of TACE $(177,178)$ compared to systemic therapy, Enrico (179) proposed a novel concept for treating intermediate-state HCC with ICIs; initiating first and delaying the use of TACE to the time-point of radiological progression (should this ever occur) and confining it to the targeting of progressive lesions to reduce the proportion of liver parenchyma exposed to the collateral damage potentially caused by TACE. Relative results might worth expecting. Yu et al. (180) compared 76 patients with advanced HCC who received radiotherapy before and/or during the administration of nivolumab with nivolumab monotherapy and found that patients who had received previous/concurrent radiotherapy had a significantly longer PFS $(\mathrm{P}=0.008)$ and $\mathrm{OS}(\mathrm{P}=0.007)$ than those who did not receive radiotherapy. However, this trend was not observed in patients with a history of RFA or TACE (all P>0.05).

Thirdly, the administration route and dosage form need to be determined: there are off-target toxicity concerns, especially with immunotherapy approaches targeting TAA 
that can target not only tumor cells but also non-tumor tissues that express target receptors, thus predisposing patients to organ damage (38,181-184). Systemic administration is also prone to cytokine storms and produces toxic side effects such as CRS (185). In particular, the greatest challenge to OVs' efficacy is adequate drug delivery because systemically administered OVs are rapidly and massively cleared by the body's antiviral immune defenses, greatly reducing their bioavailability $(70,186)$. There is also increased clearance with intratumoral injection $(187,188)$. However, interventional therapy can employ various new and unique carriers, such as polymeric micelles, nanoparticles, drug-loaded microspheres, covered stents, or other implants, to load and deliver drugs to achieve targeted and controlled release. Researchers have found that the extended-release of innate immunity-including agonists of Toll-like receptor 7/8 (TLR7/8) or STING from a biodegradable hydrogel placed in the tumor resection site cured a much higher percentage of animals than systemic or local administration of the same therapy in solution (189). Another study showed that a single intratumoral administration of the adenovirus (Ad)/hydrogel modality might prolong and potentiate the therapeutic efficacy of Ad, modulate the immune reaction in favor of the virotherapy, and enhance intratumoral localization of the virus, ultimately overcoming the limitations of oncolytic virotherapy revealed in recent clinical trials (190).

Also, it should be noted that the "cold" and "hot" classification of tumors has significant potential for guiding treatment; however, it is not the only factor determining the effect of immunotherapy. In contrast, the Immunoscore system itself has inadequacies (28), such as the strict pathological guidelines and experimental manipulation required for immune scoring and deviation from predetermined standardized operating procedures, leading to incorrect quantification of immune scores. In general, to better predict therapeutic efficacy, more comprehensive analysis methods need to be urgently established. This may involve specific imaging technologies of the TME and efficient early biomarkers, such as PD-L1 overexpression, neoantigens, genetic and epigenetic signatures, and microsatellite instability tumor resident memory $\mathrm{T}$ cells, matrix-derived immune biomarkers, and increased glycolysis (191-194).

\section{Acknowledgments}

Funding: Dr. Yueqi Zhu: Shanghai Municipal Education
Commission-Gaofeng Clinical Medicine Grant Support (No. 20152528); Shanghai Jiao Tong University "Medical and Research" Program (ZH2018ZDA19). Dr. Yingsheng Cheng: the National Nature Science Foundation of China (81571773, 81771943, and 81971714).

\section{Footnote}

Conflicts of Interest: All authors have completed the ICMJE uniform disclosure form (available at http://dx.doi. org/10.21037/qims-20-173). The authors have no conflicts of interest to declare.

Open Access Statement: This is an Open Access article distributed in accordance with the Creative Commons Attribution-NonCommercial-NoDerivs 4.0 International License (CC BY-NC-ND 4.0), which permits the noncommercial replication and distribution of the article with the strict proviso that no changes or edits are made and the original work is properly cited (including links to both the formal publication through the relevant DOI and the license). See: https://creativecommons.org/licenses/by-nc-nd/4.0/.

\section{References}

1. Syn NL, Teng MWL, Mok TSK, Soo RA. De-novo and acquired resistance to immune checkpoint targeting. Lancet Oncol 2017;18:e731-41.

2. Govindan R, Szczesna A, Ahn MJ, Schneider CP, Gonzalez Mella PF, Barlesi F, Han B, Ganea DE, Von Pawel J, Vladimirov V, Fadeeva N, Lee KH, Kurata T, Zhang L, Tamura T, Postmus PE, Jassem J, O'Byrne K, Kopit J, Li M, Tschaika M, Reck M. Phase III Trial of Ipilimumab Combined With Paclitaxel and Carboplatin in Advanced Squamous Non-Small-Cell Lung Cancer. J Clin Oncol 2017;35:3449-57.

3. Sharma A, Subudhi SK, Blando J, Scutti J, Vence L, Wargo J, Allison JP, Ribas A, Sharma P. Anti-CTLA-4 Immunotherapy Does Not Deplete FOXP3(+) Regulatory T Cells (Tregs) in Human Cancers. Clin Cancer Res 2019;25:1233-8.

4. Hellmann MD, Friedman CF, Wolchok JD. Combinatorial Cancer Immunotherapies. Adv Immunol 2016;130:251-77.

5. Du W, Yang M, Turner A, Xu C, Ferris RL, Huang J, Kane LP, Lu B. TIM-3 as a Target for Cancer Immunotherapy and Mechanisms of Action. Int J Mol Sci 2017;18:645.

6. Manieri NA, Chiang EY, Grogan JL. TIGIT: A Key Inhibitor of the Cancer Immunity Cycle. Trends Immunol 
2017;38:20-8.

7. Gao J, Ward JF, Pettaway CA, Shi LZ, Subudhi SK, Vence LM, Zhao H, Chen J, Chen H, Efstathiou E, Troncoso P, Allison JP, Logothetis CJ, Wistuba, II, Sepulveda MA, Sun J, Wargo J, Blando J, Sharma P. VISTA is an inhibitory immune checkpoint that is increased after ipilimumab therapy in patients with prostate cancer. Nat Med 2017;23:551-5.

8. van der Woude LL, Gorris MAJ, Halilovic A, Figdor CG, de Vries IJM. Migrating into the Tumor: a Roadmap for T Cells. Trends Cancer 2017;3:797-808.

9. Nolz JC. Molecular mechanisms of CD8(+) T cell trafficking and localization. Cell Mol Life Sci 2015;72:2461-73.

10. Kaufman HL, Kohlhapp FJ, Zloza A. Oncolytic viruses: a new class of immunotherapy drugs. Nat Rev Drug Discov 2015;14:642.

11. Bartlett DL, Liu Z, Sathaiah M, Ravindranathan R, Guo $\mathrm{Z}, \mathrm{He} \mathrm{Y}$, Guo ZS. Oncolytic viruses as therapeutic cancer vaccines. Mol Cancer 2013;12:103.

12. Tähtinen S, Gronberg-Vaha-Koskela S, Lumen D, Merisalo-Soikkeli M, Siurala M, Airaksinen AJ, VahaKoskela M, Hemminki A. Adenovirus Improves the Efficacy of Adoptive T-cell Therapy by Recruiting Immune Cells to and Promoting Their Activity at the Tumor. Cancer Immunol Res 2015;3:915-25.

13. Ribas A, Dummer R, Puzanov I, VanderWalde A, Andtbacka RHI, Michielin O, Olszanski AJ, Malvehy J, Cebon J, Fernandez E, Kirkwood JM, Gajewski TF, Chen L, Gorski KS, Anderson AA, Diede SJ, Lassman ME, Gansert J, Hodi FS, Long GV. Oncolytic Virotherapy Promotes Intratumoral T Cell Infiltration and Improves Anti-PD-1 Immunotherapy. Cell 2017;170:1109-19.e10.

14. Puzanov I, Milhem MM, Minor D, Hamid O, Li A, Chen LS, Chastain M, Gorski KS, Anderson A, Chou J, Kaufman HL, Andtbacka RHI. Talimogene Laherparepvec in Combination With Ipilimumab in Previously Untreated, Unresectable Stage IIIB-IV Melanoma. J Clin Oncol 2016;34:2619-26.

15. Kleinpeter P, Fend L, Thioudellet C, Geist M, Sfrontato N, Koerper V, Fahrner C, Schmitt D, Gantzer M, RemyZiller C, Brandely R, Villeval D, Rittner K, Silvestre N, Erbs P, Zitvogel L, Quéméneur E, Préville X, Marchand $J B$. Vectorization in an oncolytic vaccinia virus of an antibody, a Fab and a scFv against programmed cell death -1 (PD-1) allows their intratumoral delivery and an improved tumor-growth inhibition. Oncoimmunology 2016;5:e1220467.
16. Rosewell Shaw A, Porter CE, Watanabe N, Tanoue K, Sikora A, Gottschalk S, Brenner MK, Suzuki M. Adenovirotherapy Delivering Cytokine and Checkpoint Inhibitor Augments CAR T Cells against Metastatic Head and Neck Cancer. Mol Ther 2017;25:2440-51.

17. Borghaei H, Paz-Ares L, Horn L, Spigel DR, Steins M, Ready NE, Chow LQ, Vokes EE, Felip E, Holgado E, Barlesi F, Kohlhäufl M, Arrieta O, Burgio MA, Fayette J, Lena H, Poddubskaya E, Gerber DE, Gettinger SN, Rudin CM, Rizvi N, Crinò L, Blumenschein GR Jr, Antonia SJ, Dorange C, Harbison CT, Graf Finckenstein F, Brahmer JR. Nivolumab versus Docetaxel in Advanced Nonsquamous Non-Small-Cell Lung Cancer. N Engl J Med 2015;373:1627-39.

18. Kanjanapan Y, Day D, Wang L, Al-Sawaihey H, Abbas E, Namini A, Siu LL, Hansen A, Razak AA, Spreafico A, Leighl N, Joshua AM, Butler MO, Hogg D, Chappell MA, Soultani L, Chow K, Boujos S, Bedard PL.

Hyperprogressive disease in early-phase immunotherapy trials: Clinical predictors and association with immunerelated toxicities. Cancer 2019;125:1341-9.

19. Hodi FS, Chesney J, Pavlick AC, Robert C, Grossmann KF, McDermott DF, Linette GP, Meyer N, Giguere JK, Agarwala SS, Shaheen M, Ernstoff MS, Minor DR, Salama AK, Taylor MH, Ott PA, Horak C, Gagnier P, Jiang J, Wolchok JD, Postow MA. Combined nivolumab and ipilimumab versus ipilimumab alone in patients with advanced melanoma: 2-year overall survival outcomes in a multicentre, randomised, controlled, phase 2 trial. Lancet Oncol 2016;17:1558-68.

20. Salama AK, Moschos SJ. Next steps in immuno-oncology: enhancing antitumor effects through appropriate patient selection and rationally designed combination strategies. Ann Oncol 2017;28:57-74.

21. Galon J, Bruni D. Approaches to treat immune hot, altered and cold tumours with combination immunotherapies. Nat Rev Drug Discov 2019;18:197-218.

22. Binnewies M, Roberts EW, Kersten K, Chan V, Fearon DF, Merad M, Coussens LM, Gabrilovich DI, OstrandRosenberg S, Hedrick CC, Vonderheide RH, Pittet MJ, Jain RK, Zou W, Howcroft TK, Woodhouse EC, Weinberg RA, Krummel MF. Understanding the tumor immune microenvironment (TIME) for effective therapy. Nat Med 2018;24:541-50.

23. Wang Y, Lin HC, Huang MY, Shao Q, Wang ZQ, Wang FH, Yuan YF, Li BK, Wang DS, Ding PR, Chen G, Wu XJ, Lu ZH, Li LR, Pan ZZ, Sun P, Yan SM, Wan DS, Xu RH, $\mathrm{Li}$ YH. The Immunoscore system predicts prognosis after 
liver metastasectomy in colorectal cancer liver metastases.

Cancer Immunol Immunother 2018;67:435-44.

24. Buchan SL, Rogel A, Al-Shamkhani A. The immunobiology of CD27 and OX40 and their potential as targets for cancer immunotherapy. Blood 2018;131(1):39-48.

25. Venning FA, Wullkopf L, Erler JT. Targeting ECM Disrupts Cancer Progression. Front Oncol 2015;5:224.

26. Lanitis E, Irving M, Coukos G. Targeting the tumor vasculature to enhance $\mathrm{T}$ cell activity. Curr Opin Immunol 2015;33:55-63.

27. Rajabi M, Mousa SA. The Role of Angiogenesis in Cancer Treatment. Biomedicines 2017;5:34.

28. Angell HK, Bruni D, Barrett JC, Herbst R, Galon J. The Immunoscore: Colon Cancer and Beyond. Clin Cancer Res 2020;26:332-9.

29. Gabrilovich D. Mechanisms and functional significance of tumour-induced dendritic-cell defects. Nat Rev Immunol 2004;4:941-52.

30. Shimabukuro-Vornhagen A, Draube A, Liebig TM, Rothe A, Kochanek M, von Bergwelt-Baildon MS. The immunosuppressive factors IL-10, TGF-beta, and VEGF do not affect the antigen- presenting function of CD40activated B cells. J Exp Clin Cancer Res 2012;31:47.

31. Long GV, Dummer R, Hamid O, Gajewski T, Caglevic C, Dalle S, Arance A, Carlino MS, Grob JJ, Kim TM, Demidov LV, Robert C, Larkin JMG, Anderson J, Maleski JE, Jones MM, Diede SJ, Mitchell TC. Epacadostat (E) plus pembrolizumab $(\mathrm{P})$ versus pembrolizumab alone in patients (pts) with unresectable or metastatic melanoma: Results of the phase 3 ECHO-301/KEYNOTE-252 study. J Clin Oncol 2018;36.

32. Cannarile MA, Weisser M, Jacob W, Jegg AM, Ries $\mathrm{CH}$, Ruttinger D. Colony-stimulating factor 1 receptor (CSF1R) inhibitors in cancer therapy. J Immunother Cancer 2017;5:53.

33. De Henau O, Rausch M, Winkler D, Campesato LF, Liu C, Cymerman DH, Budhu S, Ghosh A, Pink M, Tchaicha J, Douglas M, Tibbitts T, Sharma S, Proctor J, Kosmider N, White K, Stern H, Soglia J, Adams J, Palombella VJ, McGovern K, Kutok JL, Wolchok JD, Merghoub T. Overcoming resistance to checkpoint blockade therapy by targeting PI3K $\gamma$ in myeloid cells. Nature 2016;539:443-7.

34. Moore E, Clavijo PE, Davis R, Cash H, van Waes C, Kim Y, Allen C. Established T Cell-Inflamed Tumors Rejected after Adaptive Resistance Was Reversed by Combination STING Activation and PD-1 Pathway Blockade. Cancer Immunol Res 2016;4:1061-71.

35. Clavijo PE, Moore EC, Chen JH, Davis RJ, Friedman
J, Kim Y, Waes VC, Chen Z, Allen CT. Resistance to CTLA-4 checkpoint inhibition reversed through selective elimination of granulocytic myeloid cells. Oncotarget 2017;8:55804-20.

36. Hodi FS, O'Day SJ, McDermott DF, Weber RW, Sosman JA, Haanen JB, Gonzalez R, Robert C, Schadendorf D, Hassel JC, Akerley W, van den Eertwegh AJ, Lutzky J, Lorigan P, Vaubel JM, Linette GP, Hogg D, Ottensmeier CH, Lebbé C, Peschel C, Quirt I, Clark JI, Wolchok JD, Weber JS, Tian J, Yellin MJ, Nichol GM, Hoos A, Urba WJ. Improved survival with ipilimumab in patients with metastatic melanoma. N Engl J Med 2010;363:711-23.

37. Topalian SL, Hodi FS, Brahmer JR, Gettinger SN, Smith DC, McDermott DF, Powderly JD, Carvajal RD, Sosman JA, Atkins MB, Leming PD, Spigel DR, Antonia SJ, Horn L, Drake CG, Pardoll DM, Chen L, Sharfman WH, Anders RA, Taube JM, McMiller TL, Xu H, Korman AJ, Jure-Kunkel M, Agrawal S, McDonald D, Kollia GD, Gupta A, Wigginton JM, Sznol M. Safety, Activity, and Immune Correlates of Anti-PD-1 Antibody in Cancer. N Engl J Med 2012;366:2443-54.

38. Postow MA, Sidlow R, Hellmann MD. Immune-Related Adverse Events Associated with Immune Checkpoint Blockade. New Engl J Med 2018;378:158-68.

39. Michot JM, Bigenwald C, Champiat S, Collins M, Carbonnel F, Postel-Vinay S, Berdelou A, Varga A, Bahleda R, Hollebecque A, Massard C, Fuerea A, Ribrag V, Gazzah A, Armand JP, Amellal N, Angevin E, Noel N, Boutros C, Mateus C, Robert C, Soria JC, Marabelle A, Lambotte O. Immune-related adverse events with immune checkpoint blockade: a comprehensive review. Eur J Cancer 2016;54:139-48.

40. Perez-Ruiz E, Minute L, Otano I, Alvarez M, Ochoa MC, Belsue V, de Andrea C, Rodriguez-Ruiz ME, PerezGracia JL, Marquez-Rodas I, Llacer C, Alvarez M, de Luque V, Molina C, Teijeira A, Berraondo P, Melero I. Prophylactic TNF blockade uncouples efficacy and toxicity in dual CTLA-4 and PD-1 immunotherapy. Nature 2019;569:428-32.

41. Marrone KA, Ying W, Naidoo J. Immune-Related Adverse Events From Immune Checkpoint Inhibitors. Clin Pharmacol Ther 2016;100:242-51.

42. Remolina-Bonilla YA, Jimenez-Franco B, Lam ET, Bourlon MT. Immune-Related Adverse Events Involving Multiple Organ Sites in a Patient Treated With Nivolumab Plus Ipilimumab. Oncology (Williston Park) 2020;34:171-4.

43. Weber JS, Antonia SJ, Topalian SL, Schadendorf D, Larkin JMG, Sznol M, Liu HY, Waxman I, Robert C. 
Safety profile of nivolumab (NIVO) in patients (pts) with advanced melanoma (MEL): A pooled analysis. J Clin Oncol 2015;33.

44. Lee DW, Kochenderfer JN, Stetler-Stevenson M, Cui YK, Delbrook C, Feldman SA, Fry TJ, Orentas R, Sabatino M, Shah NN, Steinberg SM, Stroncek D, Tschernia N, Yuan C, Zhang H, Zhang L, Rosenberg SA, Wayne AS, Mackall CL. T cells expressing CD19 chimeric antigen receptors for acute lymphoblastic leukaemia in children and young adults: a phase 1 dose-escalation trial. Lancet 2015;385:517-28.

45. Maude SL, Frey N, Shaw PA, Aplenc R, Barrett DM, Bunin NJ, Chew A, Gonzalez VE, Zheng Z, Lacey SF, Mahnke YD, Melenhorst JJ, Rheingold SR, Shen A, Teachey DT, Levine BL, June CH, Porter DL, Grupp SA. Chimeric antigen receptor $T$ cells for sustained remissions in leukemia. N Engl J Med 2014;371:1507-17.

46. Abate-Daga D, Lagisetty KH, Tran E, Zheng Z, Gattinoni L, Yu Z, Burns WR, Miermont AM, Teper Y, Rudloff U, Restifo NP, Feldman SA, Rosenberg SA, Morgan RA. A novel chimeric antigen receptor against prostate stem cell antigen mediates tumor destruction in a humanized mouse model of pancreatic cancer. Hum Gene Ther 2014;25:1003-12.

47. Ahmed N, Brawley VS, Hegde M, Robertson C, Ghazi A, Gerken C, Liu E, Dakhova O, Ashoori A, Corder A, Gray T, Wu MF, Liu H, Hicks J, Rainusso N, Dotti G, Mei Z, Grilley B, Gee A, Rooney CM, Brenner MK, Heslop HE, Wels WS, Wang LL, Anderson P, Gottschalk S. Human Epidermal Growth Factor Receptor 2 (HER2) -Specific Chimeric Antigen Receptor-Modified T Cells for the Immunotherapy of HER2-Positive Sarcoma. J Clin Oncol 2015;33:1688-96.

48. Hillerdal V, Ramachandran M, Leja J, Essand M. Systemic treatment with CAR-engineered $\mathrm{T}$ cells against PSCA delays subcutaneous tumor growth and prolongs survival of mice. BMC Cancer 2014;14:30.

49. Johnson LA, Scholler J, Ohkuri T, Kosaka A, Patel PR, McGettigan SE, Nace AK, Dentchev T, Thekkat P, Loew A, Boesteanu AC, Cogdill AP, Chen T, Fraietta JA, Kloss CC, Posey AD Jr, Engels B, Singh R, Ezell T, Idamakanti N, Ramones MH, Li N, Zhou L, Plesa G, Seykora JT, Okada H, June CH, Brogdon JL, Maus MV. Rational development and characterization of humanized antiEGFR variant III chimeric antigen receptor $T$ cells for glioblastoma. Sci Transl Med 2015;7:275ra22.

50. Pule MA, Savoldo B, Myers GD, Rossig C, Russell HV, Dotti G, Huls MH, Liu E, Gee AP, Mei Z, Yvon E, Weiss
HL, Liu H, Rooney CM, Heslop HE, Brenner MK. Virusspecific $\mathrm{T}$ cells engineered to coexpress tumor-specific receptors: persistence and antitumor activity in individuals with neuroblastoma. Nat Med 2008;14:1264-70.

51. Wang LCS, Lo A, Scholler J, Sun J, Majumdar RS, Kapoor V, Antzis M, Cotner CE, Johnson LA, Durham AC, Solomides CC, June CH, Pure E, Albelda SM. Targeting fibroblast activation protein in tumor stroma with chimeric antigen receptor $T$ cells can inhibit tumor growth and augment host immunity without severe toxicity. Cancer Immunol Res 2014;2:154-66.

52. Russell SJ, Peng K, Bell JC. Oncolytic virotherapy. Nat Biotechnol 2012;30:658-70.

53. Underhill DM, Ozinsky A. Phagocytosis of microbes: complexity in action. Annu Rev Immunol 2002;20:825-52.

54. French JT, Goins B, Saenz M, Li S, Garcia-Rojas X, Phillips WT, Otto RA, Bao A. Interventional therapy of head and neck cancer with lipid nanoparticlecarried rhenium 186 radionuclide. J Vasc Interv Radiol 2010;21:1271-9.

55. Chu KF, Dupuy DE. Thermal ablation of tumours: biological mechanisms and advances in therapy. Nat Rev Cancer 2014;14:199-208.

56. Dromi SA, Walsh MP, Herby S, Traughber B, Xie J, Sharma KV, Sekhar KP, Luk A, Liewehr DJ, Dreher MR, Fry TJ, Wood BJ. Radiofrequency ablation induces antigenpresenting cell infiltration and amplification of weak tumorinduced immunity. Radiology 2009;251:58-66.

57. Brown DB, Geschwind JF, Soulen MC, Millward SF, Sacks D. Society of Interventional Radiology position statement on chemoembolization of hepatic malignancies. J Vasc Interv Radiol 2006;17:217-23.

58. Llovet JM, Real MI, Montana X, Planas R, Coll S, Aponte J, Ayuso C, Sala M, Muchart J, Sola R, Rodes J, Bruix J, Barcelona Liver Cancer Group. Arterial embolisation or chemoembolisation versus symptomatic treatment in patients with unresectable hepatocellular carcinoma: a randomised controlled trial. Lancet 2002;359:1734-9.

59. Lo CM, Ngan H, Tso WK, Liu CL, Lam CM, Poon RT, Fan ST, Wong J. Randomized controlled trial of transarterial lipiodol chemoembolization for unresectable hepatocellular carcinoma. Hepatology 2002;35:1164-71.

60. Aoki T, Imamura H, Hasegawa K, Matsukura A, Sano K, Sugawara Y, Kokudo N, Makuuchi M. Sequential preoperative arterial and portal venous embolizations in patients with hepatocellular carcinoma. Arch Surg 2004;139:766-74.

61. Llovet JM, Burroughs A, Bruix J. Hepatocellular 
carcinoma. Lancet 2003;362:1907-17.

62. Arii S, Yamaoka Y, Futagawa S, Inoue K, Kobayashi K, Kojiro M, Makuuchi M, Nakamura Y, Okita K, Yamada R. Results of surgical and nonsurgical treatment for small-sized hepatocellular carcinomas: a retrospective and nationwide survey in Japan. The Liver Cancer Study Group of Japan. Hepatology 2000;32:1224-9.

63. Livraghi T, Meloni F, Morabito A, Vettori C. Multimodal image-guided tailored therapy of early and intermediate hepatocellular carcinoma: long-term survival in the experience of a single radiologic referral center. Liver Transpl 2004;10:S98-106.

64. Burger I, Hong K, Schulick R, Georgiades C, Thuluvath P, Choti M, Kamel I, Geschwind JH. Transcatheter arterial chemoembolization in unresectable cholangiocarcinoma: initial experience in a single institution. J Vasc Interv Radiol 2005;16:353-61.

65. Takaki H, Imai N, Contessa TT, Srimathveeravalli G, Covey AM, Getrajdman GI, Brown KT, Solomon SB, Erinjeri JP. Peripheral Blood Regulatory T-Cell and Type 1 Helper T-Cell Population Decrease after Hepatic Artery Embolization. J Vasc Interv Radiol 2016;27:1561-8.

66. Hickey RM, Kulik LM, Nimeiri H, Kalyan A, Kircher S, Desai K, Riaz A, Lewandowski RJ, Salem R. Immunooncology and Its Opportunities for Interventional Radiologists: Immune Checkpoint Inhibition and Potential Synergies with Interventional Oncology Procedures. J Vasc Interv Radiol 2017;28:1487-94.

67. Nobuoka D, Motomura Y, Shirakawa H, Yoshikawa T, Kuronuma T, Takahashi M, Nakachi K, Ishii H, Furuse J, Gotohda N, Takahashi S, Nakagohri T, Konishi M, Kinoshita T, Komori H, Baba H, Fujiwara T, Nakatsura T. Radiofrequency ablation for hepatocellular carcinoma induces glypican-3 peptide-specific cytotoxic $\mathrm{T}$ lymphocytes. Int J Oncol 2012;40:63-70.

68. Noman MZ, Desantis G, Janji B, Hasmim M, Karray S, Dessen P, Bronte V, Chouaib S. PD-L1 is a novel direct target of HIF-1alpha, and its blockade under hypoxia enhanced MDSC-mediated T cell activation. J Exp Med 2014;211:781-90.

69. Ayaru L, Pereira SP, Alisa A, Pathan AA, Williams R, Davidson B, Burroughs AK, Meyer T, Behboudi S. Unmasking of alpha-fetoprotein-specific CD4(+) $\mathrm{T}$ cell responses in hepatocellular carcinoma patients undergoing embolization. J Immunol 2007;178:1914-22.

70. Duffy AG, Ulahannan SV, Makorova-Rusher O, Rahma O, Wedemeyer H, Pratt D, Davis JL, Hughes MS, Heller T, ElGindi M, Uppala A, Korangy F, Kleiner DE, Figg WD,
Venzon D, Steinberg SM, Venkatesan AM, Krishnasamy V, Abi-Jaoudeh N, Levy E, Wood BJ, Greten TF. Tremelimumab in combination with ablation in patients with advanced hepatocellular carcinoma. J Hepatol 2017;66:545-51.

71. He C, Zhang Y, Lin X. Increased Overall Survival and Decreased Cancer-Specific Mortality in Patients with Hepatocellular Carcinoma Treated by Transarterial Chemoembolization and Human Adenovirus Type5 Combination Therapy: a Competing Risk Analysis. J Gastrointest Surg 2018;22:989-97.

72. He Q, Liu Y, Zou Q, Guan YS. Transarterial injection of H101 in combination with chemoembolization overcomes recurrent hepatocellular carcinoma. World J Gastroenterol 2011;17:2353-5.

73. Huang ZM, Li W, Li S, Gao F, Zhou QM, Wu FM, He N, Pan CC, Xia JC, Wu PH, Zhao M. Cytokineinduced killer cells in combination with transcatheter arterial chemoembolization and radiofrequency ablation for hepatocellular carcinoma patients. J Immunother 2013;36:287-93.

74. Guo Z, Meng C, Wei X, Tang C, Liang J. Combination nivolumab with transcatheter arterial chemoembolization for clinical remission of small cell lung cancer: A case report. Thorac Cancer 2018;9:646-51.

75. Stuart K. Chemoembolization in the management of liver tumors. Oncologist 2003;8:425-37.

76. Miraglia R, Pietrosi G, Maruzzelli L, Petridis I, Caruso S, Marrone G, Mamone G, Vizzini G, Luca A, Gridelli B. Efficacy of transcatheter embolization/chemoembolization (TAE/TACE) for the treatment of single hepatocellular carcinoma. World J Gastroenterol 2007;13:2952-5.

77. Higuchi T, Kikuchi M, Okazaki M. Hepatocellular carcinoma after transcatheter hepatic arterial embolization. A histopathologic study of 84 resected cases. Cancer 1994;73:2259-67.

78. Kobayashi N, Ishii M, Ueno Y, Kisara N, Chida N, Iwasaki T, Toyota T. Co-expression of Bcl-2 protein and vascular endothelial growth factor in hepatocellular carcinomas treated by chemoembolization. Liver 1999;19:25-31.

79. Xiong ZP, Yang SR, Liang ZY, Xiao EH, Yu XP, Zhou SK, Zhang ZS. Association between vascular endothelial growth factor and metastasis after transcatheter arterial chemoembolization in patients with hepatocellular carcinoma. Hepatobiliary Pancreat Dis Int 2004;3:386-90.

80. Agolli L, Nicosia L. Recent prospective data regarding good survival outcome after radiofrequency ablation of lung metastases from colorectal cancer: the radiation 
oncologist point of view. Quant Imaging Med Surg 2020;10:1182-5.

81. Dupuy DE, Liu D, Hartfeil D, Hanna L, Blume JD, Ahrar K, Lopez R, Safran H, DiPetrillo T. Percutaneous radiofrequency ablation of painful osseous metastases: a multicenter American College of Radiology Imaging Network trial. Cancer 2010;116:989-97.

82. Hadjicostas P, Malakounides N, Varianos C, Kitiris E, Lerni F, Symeonides P. Radiofrequency ablation in pancreatic cancer. HPB (Oxford) 2006;8:61-4.

83. Ma J, Wang F, Zhang W, Wang L, Yang X, Qian Y, Huang J, Wang J, Yang J. Percutaneous cryoablation for the treatment of liver cancer at special sites: an assessment of efficacy and safety. Quant Imaging Med Surg 2019;9:1948-57.

84. Rosenthal DI, Hornicek FJ, Torriani M, Gebhardt MC, Mankin HJ. Osteoid osteoma: percutaneous treatment with radiofrequency energy. Radiology 2003;229:171-5.

85. Weber MA, Sprengel SD, Omlor GW, Lehner B, Wiedenhofer B, Kauczor HU, Rehnitz C. Clinical long-term outcome, technical success, and cost analysis of radiofrequency ablation for the treatment of osteoblastomas and spinal osteoid osteomas in comparison to open surgical resection. Skeletal Radiol 2015;44:981-93.

86. Rimondi E, Mavrogenis AF, Rossi G, Ciminari R, Malaguti C, Tranfaglia C, Vanel D, Ruggieri P. Radiofrequency ablation for non-spinal osteoid osteomas in 557 patients. Eur Radiol 2012;22:181-8.

87. Gurdezi S, White T, Ramesh P. Alcohol injection for Morton's neuroma: a five-year follow-up. Foot Ankle Int 2013;34:1064-7.

88. Loesch MM, Somani AK, Kingsley MM, Travers JB, Spandau DF. Skin resurfacing procedures: new and emerging options. Clin Cosmet Investig Dermatol 2014;7:231-41.

89. Fleischer DE, Overholt BF, Sharma VK, Reymunde A, Kimmey MB, Chuttani R, Chang KJ, Muthasamy R, Lightdale CJ, Santiago N, Pleskow DK, Dean PJ, Wang KK. Endoscopic radiofrequency ablation for Barrett's esophagus: 5-year outcomes from a prospective multicenter trial. Endoscopy 2010;42:781-9.

90. Shaheen NJ, Sharma P, Overholt BF, Wolfsen HC, Sampliner RE, Wang KK, Galanko JA, Bronner MP, Goldblum JR, Bennett AE, Jobe BA, Eisen GM, Fennerty MB, Hunter JG, Fleischer DE, Sharma VK, Hawes RH, Hoffman BJ, Rothstein RI, Gordon SR, Mashimo H, Chang KJ, Muthusamy VR, Edmundowicz SA, Spechler SJ, Siddiqui AA, Souza RF, Infantolino A, Falk GW,
Kimmey MB, Madanick RD, Chak A, Lightdale CJ. Radiofrequency ablation in Barrett's esophagus with dysplasia. N Engl J Med 2009;360:2277-88.

91. Shaheen NJ, Overholt BF, Sampliner RE, Wolfsen HC, Wang KK, Fleischer DE, Sharma VK, Eisen GM, Fennerty MB, Hunter JG, Bronner MP, Goldblum JR, Bennett AE, Mashimo H, Rothstein RI, Gordon SR, Edmundowicz SA, Madanick RD, Peery AF, Muthusamy VR, Chang KJ, Kimmey MB, Spechler SJ, Siddiqui AA, Souza RF, Infantolino A, Dumot JA, Falk GW, Galanko JA, Jobe BA, Hawes RH, Hoffman BJ, Sharma P, Chak A, Lightdale CJ. Durability of radiofrequency ablation in Barrett's esophagus with dysplasia. Gastroenterology 2011;141:460-8.

92. van Vilsteren FG, Pouw RE, Seewald S, Herrero LA, Sondermeijer CMT, Visser M, Ten Kate FJW, Teng KCYK, Soehendra N, Rosch T, Weusten BLAM, Bergman JJGHM. Stepwise radical endoscopic resection versus radiofrequency ablation for Barrett's oesophagus with high-grade dysplasia or early cancer: a multicentre randomised trial. Gut 2011;60:765-73.

93. den Brok MH, Sutmuller RPM, van der Voort R, Bennink EJ, Figdor CG, Ruers TJM, Adema GJ. In situ tumor ablation creates an antigen source for the generation of antitumor immunity. Cancer Res 2004;64:4024-9.

94. Wissniowski TT, Hunsler J, Neureiter D, Frieser M, Schaber S, Esslinger B, Voll R, Strobel D, Hahn EG, Schuppan D. Activation of tumor-specific T lymphocytes by radio-frequency ablation of the VX2 hepatoma in rabbits. Cancer Res 2003;63:6496-500. Corrected in Cancer Res 2003;63:7543.

95. Liu GJ, Moriyasu F, Hirokawa T, Rexiati M, Yamada M, Imai Y. Expression of Heat Shock Protein 70 in Rabbit Liver after Contrast-Enhanced Ultrasound and Radiofrequency Ablation. Ultrasound Med Biol 2010;36:78-85.

96. Rai R, Richardson C, Flecknell P, Robertson H, Burt A, Manas DM. Study of apoptosis and heat shock protein (HSP) expression in hepatocytes following radiofrequency ablation (RFA). J Surg Res 2005;129:147-51.

97. Schueller G, Kettenbach J, Sedivy R, Stift A, Friedl J, Gnant $M$, Lammer J. Heat shock protein expression induced by percutaneous radiofrequency ablation of hepatocellular carcinoma in vivo. Int J Oncol 2004;24:609-13.

98. Troy AJ, Summers KL, Davidson PJ, Atkinson CH, Hart DN. Minimal recruitment and activation of dendritic cells within renal cell carcinoma. Clin Cancer Res 1998;4:585-93. 
99. Wang Y, Singh NK, Spear TT, Hellman LM, Piepenbrink KH, McMahan RH, Rosen HR, Vander Kooi CW, Nishimura M, Baker BM. How an alloreactive T-cell receptor achieves peptide and MHC specificity. Proc Natl Acad Sci U S A 2017;114:E4792-801.

100. Machlenkin A, Goldberger O, Tirosh B, Paz A, Volovitz I, Bar-Haim E, Lee SH, Vadai E, Tzehoval E, Eisenbach

L. Combined dendritic cell cryotherapy of tumor induces systemic antimetastatic immunity. Clin Cancer Res 2005;11:4955-61.

101.Bäcklund M, Freedman J. Microwave Ablation and Immune Activation in the Treatment of Recurrent Colorectal Lung Metastases: A Case Report. Case Rep Oncol 2017;10:383-7.

102. Yin J, Dong J, Gao W, Wang Y. A case report of remarkable response to association of radiofrequency ablation with subsequent Atezolizumab in stage IV nonsmall cell lung cancer. Medicine (Baltimore) 2018;97:e13112.

103. Soule E, Bandyk M, Matteo J. Percutaneous ablative cryoimmunotherapy for micrometastaic abscopal effect: No complications. Cryobiology 2018;82:22-6.

104. Waitz R, Solomon SB, Petre EN, Trumble AE, Fasso $\mathrm{M}$, Norton L, Allison JP. Potent Induction of Tumor Immunity by Combining Tumor Cryoablation with AntiCTLA-4 Therapy. Cancer Res 2012;72:430-9.

105. Shi L, Chen L, Wu C, Zhu Y, Xu B, Zheng X, Sun M, Wen W, Dai X, Yang M, Lv Q, Lu B, Jiang J. PD-1 Blockade Boosts Radiofrequency Ablation-Elicited Adaptive Immune Responses against Tumor. Clin Cancer Res 2016;22:1173-84.

106. Chen Q, Hu Q, Dukhovlinova E, Chen G, Ahn S, Wang C, Ogunnaike EA, Ligler FS, Dotti G, Gu Z. Photothermal Therapy Promotes Tumor Infiltration and Antitumor Activity of CAR T Cells. Adv Mater 2019;31:e1900192.

107. Blanchard M, Shim KG, Grams MP, Rajani K, Diaz RM, Furutani KM, Thompson J, Olivier KR, Park SS, Markovic SN, Pandha H, Melcher A, Harrington K, Zaidi S, Vile R. Definitive Management of Oligometastatic Melanoma in a Murine Model Using Combined Ablative Radiation Therapy and Viral Immunotherapy. Int J Radiat Oncol Biol Phys 2015;93:577-87.

108.Zhao J, Wen X, Tian L, Li T, Xu C, Wen X, Melancon MP, Gupta S, Shen B, Peng W, Li C. Irreversible electroporation reverses resistance to immune checkpoint blockade in pancreatic cancer. Nat Commun 2019;10:899.

109. Rozenblum N, Zeira E, Scaiewicz V, Bulvik B, Gourevitch S, Yotvat H, Galun E, Goldberg SN. Oncogenesis: an "off-target" effect of radiofrequency ablation. Radiology 2015;276:426-32.

110.Ahmed M, Kumar G, Moussa M, Wang YG, Rozenblum N, Galun E, Goldberg SN. Hepatic Radiofrequency Ablation-induced Stimulation of Distant Tumor Growth Is Suppressed by c-Met Inhibition. Radiology 2016;279:103-17.

111.Velez E, Goldberg SN, Kumar G, Wang YG, Gourevitch S, Sosna J, Moon T, Brace CL, Ahmed M. Hepatic Thermal Ablation: Effect of Device and Heating Parameters on Local Tissue Reactions and Distant Tumor Growth. Radiology 2016;281:782-92.

112. Balan M, Teran EMY, Waaga-Gasser AM, Gasser M, Choueiri TK, Freeman G, Pal S. Novel Roles of c-Met in the Survival of Renal Cancer Cells through the Regulation of HO-1 and PD-L1 Expression. J Biol Chem 2015;290:8110-20.

113. Chen MF, Chen PT, Chen WC, Lu MS, Lin PY, Lee KD. The role of PD-L1 in the radiation response and prognosis for esophageal squamous cell carcinoma related to IL-6 and T-cell immunosuppression. Oncotarget 2016;7:7913-24.

114. Kishan AU, Cook RR, Ciezki JP, Ross AE, Pomerantz MM, Nguyen PL, Shaikh T, Tran PT, Sandler KA, Stock RG, Merrick GS, Demanes DJ, Spratt DE, Abu-Isa EI, Wedde TB, Lilleby W, Krauss DJ, Shaw GK, Alam R, Reddy CA, Stephenson AJ, Klein EA, Song DY, Tosoian JJ, Hegde JV, Yoo SM, Fiano R, D'Amico AV, Nickols NG, Aronson WJ, Sadeghi A, Greco S, Deville C, McNutt T, DeWeese TL, Reiter RE, Said JW, Steinberg ML, Horwitz EM, Kupelian PA, King CR. Radical Prostatectomy, External Beam Radiotherapy, or External Beam Radiotherapy With Brachytherapy Boost and Disease Progression and Mortality in Patients With Gleason Score 9-10 Prostate Cancer. JAMA 2018;319:896-905.

115.Pieters BR, de Back DZ, Koning CCE, Zwinderman AH. Comparison of three radiotherapy modalities on biochemical control and overall survival for the treatment of prostate cancer: A systematic review. Radiother Oncol 2009;93:168-73.

116. Burnette B, Weichselbaum RR. Radiation as an Immune Modulator. Semin Radiat Oncol 2013;23:273-80.

117.Demaria S, Formenti SC. Radiotherapy effects on antitumor immunity: implications for cancer treatment. Front Oncol 2013;3:128.

118. Formenti SC, Demaria S. Combining Radiotherapy and Cancer Immunotherapy: A Paradigm Shift. J Natl Cancer Inst 2013;105:256-65.

119. Manda K, Glasow A, Paape D, Hildebrandt G. Effects 
of ionizing radiation on the immune system with special emphasis on the interaction of dendritic and T cells. Front Oncol 2012;2:102.

120.Park B, Yee C, Lee KM. The Effect of Radiation on the Immune Response to Cancers. Int J Mol Sci 2014;15:927-43.

121. Soliman HH, Jackson E, Neuger T, Dees EC, Harvey RD, Han H, Ismail-Khan R, Minton S, Vahanian NN, Link C, Sullivan DM, Antonia S. A first in man phase I trial of the oral immunomodulatory, indoximod, combined with docetaxel in patients with metastatic solid tumors. Oncotarget 2014;5:8136-46.

122. Ngwa W, Irabor OC, Schoenfeld JD, Hesser J, Demaria S, Formenti SC. Using immunotherapy to boost the abscopal effect. Nat Rev Cancer 2018;18:313-22.

123. Weichselbaum RR, Liang H, Deng L, Fu YX. Radiotherapy and immunotherapy: a beneficial liaison? Nat Rev Clin Oncol 2017;14:365-79.

124. Golden EB, Frances D, Pellicciotta I, Demaria S, Barcellos-Hoff MH, Formenti SC. Radiation fosters dosedependent and chemotherapy-induced immunogenic cell death. Oncoimmunology 2014;3:e28518.

125.Krysko DV, Garg AD, Kaczmarek A, Krysko O, Agostinis $\mathrm{P}$, Vandenabeele P. Immunogenic cell death and DAMPs in cancer therapy. Nat Rev Cancer 2012;12:860-75.

126. Krysko O, Aaes TL, Bachert C, Vandenabeele P, Krysko DV. Many faces of DAMPs in cancer therapy. Cell Death Dis 2013;4:e631.

127.McBride WH, Chiang CS, Olson JL, Wang CC, Hong JH, Pajonk F, Dougherty GJ, Iwamoto KS, Pervan M, Liao YP. Failla Memorial Lecture - A sense of danger from radiation. Radiat Res 2004;162:1-19.

128. Obeid M, Tesniere A, Ghiringhelli F, Fimia GM, Apetoh L, Perfettini JL, Castedo M, Mignot G, Panaretakis T, Casares N, Metivier D, Larochette N, van Endert P, Ciccosanti F, Piacentini M, Zitvogel L, Kroemer G. Calreticulin exposure dictates the immunogenicity of cancer cell death. Nat Med 2007;13:54-61.

129.Zitvogel L, Kepp O, Kroemer G. Decoding Cell Death Signals in Inflammation and Immunity. Cell 2010;140:798-804.

130. Bahary N, GarridoLaguna I, Cinar P, O'Rourke MA, Somer BG, Nyakkapoor A, Lee JS, Munn D, Kennedy EP, Vahanian NN. Phase 2 trial of the indoleamine 2,3-dioxygenase pathway (IDO) inhibitor indoximod plus gemcitabine/nab-paclitaxel for the treatment of metastatic pancreas cancer: Interim analysis. J Clin Oncol 2016;34(15).

131.Gupta A, Probst HC, Vuong V, Landshammer A, Muth S,
Yagita H, Schwendener R, Pruschy M, Knuth A, van den Broek M. Radiotherapy Promotes Tumor-Specific Effector CD8(+) T Cells via Dendritic Cell Activation. J Immunol 2012;189:558-66.

132. Sharabi AB, Nirschl CJ, Kochel CM, Nirschl TR, Francica BJ, Velarde E, Deweese TL, Drake CG. Stereotactic Radiation Therapy Augments Antigen-Specific PD1-Mediated Antitumor Immune Responses via CrossPresentation of Tumor Antigen. Cancer Immunol Res 2015;3:345-55.

133.Apetoh L, Ghiringhelli F, Tesniere A, Obeid M, Ortiz C, Criollo A, Mignot G, Maiuri MC, Ullrich E, Saulnier P, Yang H, Amigorena S, Ryffel B, Barrat FJ, Saftig P, Levi F, Lidereau R, Nogues C, Mira JP, Chompret A, Joulin V, Clavel-Chapelon F, Bourhis J, André F, Delaloge S, Tursz

T, Kroemer G, Zitvogel L. Toll-like receptor 4-dependent contribution of the immune system to anticancer chemotherapy and radiotherapy. Nat Med 2007;13:1050-9.

134.Hallahan DE, Spriggs DR, Beckett MA, Kufe DW, Weichselbaum RR. Increased tumor necrosis factor $\alpha$ mRNA after cellular exposure to ionizing radiation. Proc Natl Acad Sci U S A 1989;86:10104-7.

135.Fu Y, Wang Y, Du L, Xu C, Cao J, Fan T, Liu J, Su X, Fan S, Liu Q, Fan F. Resveratrol Inhibits Ionising IrradiationInduced Inflammation in MSCs by Activating SIRT1 and Limiting NLRP-3 Inflammasome Activation. Int J Mol Sci 2013;14:14105-18.

136. Hallahan DE, Virudachalam S, Sherman ML, Huberman E, Kufe DW, Weichselbaum RR. Tumor necrosis factor gene expression is mediated by protein kinase $\mathrm{C}$ following activation by ionizing radiation. Cancer Res 1991;51:4565-9.

137. Pasi F, Paolini A, Nano R, Di Liberto R, Capelli E. Effects of Single or Combined Treatments with Radiation and Chemotherapy on Survival and Danger Signals Expression in Glioblastoma Cell Lines. Biomed Res Int 2014;2014:453497.

138. Vanpouille-Box C, Diamond JM, Pilones KA, Zavadil J, Babb JS, Formenti SC, Barcellos-Hoff MH, Demaria S. TGF $\beta$ Is a Master Regulator of Radiation Therapy-Induced Antitumor Immunity. Cancer Res 2015;75:2232-42.

139. Matsumura S, Wang B, Kawashima N, Braunstein S, Badura M, Cameron TO, Babb JS, Schneider RJ, Formenti SC, Dustin ML, Demaria S. Radiation-induced CXCL16 release by breast cancer cells attracts effector $T$ cells. J Immunol 2008;181:3099-107.

140.Meng Y, Mauceri HJ, Khodarev NN, Darga TE, Pitroda SP, Beckett MA, Kufe DW, Weichselbaum RR. Ad.Egr$\mathrm{TNF}$ and local ionizing radiation suppress metastases by 
interferon-beta-dependent activation of antigen-specific CD8+ T cells. Mol Ther 2010;18:912-20.

141.Demaria S, Formenti SC. Radiation as an immunological adjuvant: current evidence on dose and fractionation. Front Oncol 2012;2:153.

142.Demaria S, Formenti SC. Role of T lymphocytes in tumor response to radiotherapy. Front Oncol 2012;2:95.

143. Deng L, Liang H, Burnette B, Beckett M, Darga T, Weichselbaum RR, Fu YX. Irradiation and anti-PD-L1 treatment synergistically promote antitumor immunity in mice. J Clin Invest 2014;124:687-95.

144. Schaue D, Kachikwu EL, McBride WH. Cytokines in Radiobiological Responses: A Review. Radiat Res 2012;178:505-23.

145. Wirsdörfer F, Cappuccini F, Niazman M, de Leve S, Westendorf AM, Ludemann L, Stuschke M, Jendrossek V. Thorax irradiation triggers a local and systemic accumulation of immunosuppressive CD4+FoxP3+regulatory T cells. Radiat Oncol 2014;9:98.

146. Chang X, Lu X, Guo J, Teng GJ. Interventional therapy combined with immune checkpoint inhibitors: Emerging opportunities for cancer treatment in the era of immunotherapy. Cancer Treat Rev 2019;74:49-60.

147.Herrera FG, Bourhis J, Coukos G. Radiotherapy combination opportunities leveraging immunity for the next oncology practice. CA Cancer J Clin 2017;67:65-85.

148. Dovedi SJ, Adlard AL, Lipowska-Bhalla G, McKenna C, Jones S, Cheadle EJ, Stratford IJ, Poon E, Morrow M, Stewart R, Jones H, Wilkinson RW, Honeychurch J, Illidge TM. Acquired Resistance to Fractionated Radiotherapy Can Be Overcome by Concurrent PD-L1 Blockade. Cancer Res 2014;74:5458-68.

149. Confino H, Schmidt M, Efrati M, Hochman I, Umansky V, Kelson I, Keisari Y. Inhibition of mouse breast adenocarcinoma growth by ablation with intratumoral alpha-irradiation combined with inhibitors of immunosuppression and CpG. Cancer Immunol Immunother 2016;65:1149-58.

150.Kwon ED, Drake CG, Scher HI, Fizazi K, Bossi A, van den Eertwegh AJ, Krainer M, Houede N, Santos R, Mahammedi H, Ng S, Maio M, Franke FA, Sundar S, Agarwal N, Bergman AM, Ciuleanu TE, Korbenfeld E, Sengeløv L, Hansen S, Logothetis C, Beer TM, McHenry MB, Gagnier P, Liu D, Gerritsen WR; CA184-043 Investigators. Ipilimumab versus placebo after radiotherapy in patients with metastatic castration-resistant prostate cancer that had progressed after docetaxel chemotherapy (CA184-043): a multicentre, randomised, double-blind, phase 3 trial. Lancet Oncol 2014;15:700-12.

151. Twyman-Saint Victor C, Rech AJ, Maity A, Rengan R, Pauken KE, Stelekati E, Benci JL, Xu B, Dada H, Odorizzi PM, Herati RS, Mansfield KD, Patsch D, Amaravadi RK, Schuchter LM, Ishwaran H, Mick R, Pryma DA, Xu X, Feldman MD, Gangadhar TC, Hahn SM, Wherry EJ, Vonderheide RH, Minn AJ. Radiation and dual checkpoint blockade activate non-redundant immune mechanisms in cancer. Nature 2015;520:373.

152. Heery CR, Madan RA, Stein MN, Stadler WM, Di Paola RS, Rauckhorst M, Steinberg SM, Marté JL, Chen CC, Grenga I, Donahue RN, Jochems C, Dahut WL, Schlom J, Gulley JL. Samarium-153-EDTMP (Quadramet) with or without vaccine in metastatic castration-resistant prostate cancer: A randomized Phase 2 trial. Oncotarget 2016;7:69014-23.

153. Moan J, Peng Q. An outline of the hundred-year history of PDT. Anticancer Res 2003;23:3591-600.

154.Dolmans DE, Fukumura D, Jain RK. Photodynamic therapy for cancer. Nat Rev Cancer 2003;3:380-7.

155.Xiao J, Cheng L, Fang T, Zhang Y, Zhou J, Cheng R, Tang W, Zhong X, Lu Y, Deng L, Cheng Y, Zhu Y, Liu Z, Cui W. Nanoparticle-Embedded Electrospun Fiber-Covered Stent to Assist Intraluminal Photodynamic Treatment of Oesophageal Cancer. Small 2019;15:e1904979.

156. Castano AP, Demidova TN, Hamblin MR. Mechanisms in photodynamic therapy: part two-cellular signaling, cell metabolism and modes of cell death. Photodiagnosis Photodyn Ther 2005;2:1-23.

157. Castano AP, Demidova TN, Hamblin MR. Mechanisms in photodynamic therapy: Part three- Photosensitizer pharmacokinetics, biodistribution, tumor localization and modes of tumor destruction. Photodiagnosis Photodyn Ther 2005;2:91-106.

158. Castano AP, Mroz P, Hamblin MR. Photodynamic therapy and anti-tumour immunity. Nat Rev Cancer 2006;6:535-45.

159. Oleinick NL, Morris RL, Belichenko T. The role of apoptosis in response to photodynamic therapy: what, where, why, and how. Photochem Photobiol Sci 2002;1:1-21.

160. Dolmans DEJGJ, Kadambi A, Hill JS, Waters CA, Robinson BC, Walker JP, Fukumura D, Jain RK. Vascular accumulation of a novel photosensitizer, MV6401, causes selective thrombosis in tumor vessels after photodynamic therapy. Cancer Res 2002;62:2151-6.

161. Krammer B. Vascular effects of photodynamic therapy. Anticancer Res 2001;21:4271-7.

162. Babilas P, Schreml S, Landthaler M, Szeimies RM. Photodynamic therapy in dermatology: state-of-the-art. 
Photodermatol Photoimmunol Photomed 2010;26:118-32. 163. Yazdani Abyaneh MA, Falto-Aizpurua L, Griffith RD, Nouri K. Photodynamic therapy for actinic cheilitis: a systematic review. Dermatol Surg 2015;41:189-98.

164. Morton C, Horn M, Leman J, Tack B, Bedane C, Tjioe M, Ibbotson S, Khemis A, Wolf P. Comparison of topical methyl aminolevulinate photodynamic therapy with cryotherapy or Fluorouracil for treatment of squamous cell carcinoma in situ: Results of a multicenter randomized trial. Arch Dermatol 2006;142:729-35.

165. Salim A, Leman JA, McColl JH, Chapman R, Morton CA. Randomized comparison of photodynamic therapy with topical 5-fluorouracil in Bowen's disease. Br J Dermatol 2003;148:539-43.

166.Zheng W, Wu Y, Xu X, Gao X, Chen HD, Li Y. Evidencebased review of photodynamic therapy in the treatment of acne. Eur J Dermatol 2014;24:444-56.

167. Canti G, De Simone A, Korbelik M. Photodynamic therapy and the immune system in experimental oncology. Photochem Photobiol Sci 2002;1:79-80.

168. Kaneko K, Osada T, Haystead TA, Morse MA, Lyerly HK. Induction of enhanced tumor-specific immunity by Hsp90 targeted photodynamic therapy (Hsp90-PDT) combined with immune checkpoint inhibition. Cancer Res 2017;77.

169.van Duijnhoven FH, Aalbers RIJM, Rovers JP, Terpstra OT, Kuppen PJK. The immunological consequences of photodynamic treatment of cancer, a literature review. Immunobiology 2003;207:105-13.

170.Duan X, Chan C, Guo N, Han W, Weichselbaum RR, Lin W. Photodynamic Therapy Mediated by Nontoxic Core-Shell Nanoparticles Synergizes with Immune Checkpoint Blockade To Elicit Antitumor Immunity and Antimetastatic Effect on Breast Cancer. J Am Chem Soc 2016;138:16686-95.

171.He C, Duan X, Guo N, Chan C, Poon C, Weichselbaum $\mathrm{RR}$, Lin W. Core-shell nanoscale coordination polymers combine chemotherapy and photodynamic therapy to potentiate checkpoint blockade cancer immunotherapy. Nat Commun 2016;7:12499.

172. Ou W, Jiang L, Thapa RK, Soe ZC, Poudel K, Chang JH, Ku SK, Choi HG, Yong CS, Kim JO. Combination of NIR therapy and regulatory $\mathrm{T}$ cell modulation using layer-by-layer hybrid nanoparticles for effective cancer photoimmunotherapy. Theranostics 2018;8:4574-90.

173. Gil M, Bieniasz M, Seshadri M, Fisher D, Ciesielski MJ, Chen Y, Pandey RK, Kozbor D. Photodynamic therapy augments the efficacy of oncolytic vaccinia virus against primary and metastatic tumours in mice. Br J Cancer
2011;105:1512-21.

174.Lansbury L, Bath-Hextall F, Perkins W, Stanton W, Leonardi-Bee J. Interventions for non-metastatic squamous cell carcinoma of the skin: systematic review and pooled analysis of observational studies. BMJ 2013;347:f6153.

175.Shi L, Wang J, Ding N, Zhang Y, Zhu Y, Dong S, Wang X, Peng C, Zhou C, Zhou L, Li X, Shi H, Wu W, Long $\mathrm{X}, \mathrm{Wu} \mathrm{C}, \mathrm{Liao} \mathrm{W}$. Inflammation induced by incomplete radiofrequency ablation accelerates tumor progression and hinders PD-1 immunotherapy. Nat Commun 2019;10:5421.

176. Kim C, Hoang CD, Kesarwala AH, Schrump DS, Guha U, Rajan A. Role of Local Ablative Therapy in Patients with Oligometastatic and Oligoprogressive Non-Small Cell Lung Cancer. J Thorac Oncol 2017;12:179-93.

177.Labeur TA, Runge JH, Klompenhouwer EG, Klümpen HJ, Takkenberg RB, van Delden OM. Diffusionweighted imaging of hepatocellular carcinoma before and after transarterial chemoembolization: role in survival prediction and response evaluation. Abdom Radiol (NY) 2019;44:2740-50.

178.Lencioni R, de Baere T, Soulen MC, Rilling WS, Geschwind JFH. Lipiodol transarterial chemoembolization for hepatocellular carcinoma: A systematic review of efficacy and safety data. Hepatology 2016;64:106-16.

179. De Toni EN. Immune checkpoint inhibitors: use them early, combined and instead of TACE? Gut 2020;69:1887-8.

180. Yu JI, Lee SJ, Lee J, Lim HY, Paik SW, Yoo GS, Choi C, Park HC. Clinical significance of radiotherapy before and/or during nivolumab treatment in hepatocellular carcinoma. Cancer Med 2019;8:6986-94.

181.Eggermont AM, Chiarion-Sileni V, Grob JJ, Dummer R, Wolchok JD, Schmidt H, Hamid O, Robert C, Ascierto PA, Richards JM, Lebbé C, Ferraresi V, Smylie M, Weber JS, Maio M, Bastholt L, Mortier L, Thomas L, Tahir S, Hauschild A, Hassel JC, Hodi FS, Taitt C, de Pril V, de Schaetzen G, Suciu S, Testori A. Prolonged Survival in Stage III Melanoma with Ipilimumab Adjuvant Therapy. New Engl J Med 2016;375:1845-55.

182. Cameron BJ, Gerry AB, Dukes J, Harper JV, Kannan V, Bianchi FC, Grand F, Brewer JE, Gupta M, Plesa G, Bossi G, Vuidepot A, Powlesland AS, Legg A, Adams KJ, Bennett AD, Pumphrey NJ, Williams DD, BinderScholl G, Kulikovskaya I, Levine BL, Riley JL, VarelaRohena A, Stadtmauer EA, Rapoport AP, Linette GP, June $\mathrm{CH}$, Hassan NJ, Kalos M, Jakobsen BK. Identification of a Titin-derived HLA-A1-presented peptide as a crossreactive target for engineered MAGE A3-directed $\mathrm{T}$ cells. 
Sci Transl Med 2013;5:197ra103.

183. Linette GP, Stadtmauer EA, Maus MV, Rapoport AP, Levine BL, Emery L, Litzky L, Bagg A, Carreno BM, Cimino PJ, Binder-Scholl GK, Smethurst DP, Gerry AB, Pumphrey NJ, Bennett AD, Brewer JE, Dukes J, Harper J, Tayton-Martin HK, Jakobsen BK, Hassan NJ, Kalos M, June CH. Cardiovascular toxicity and titin cross-reactivity of affinity-enhanced $\mathrm{T}$ cells in myeloma and melanoma. Blood 2013;122:863-71.

184. Morgan RA, Chinnasamy N, Abate-Daga D, Gros A, Robbins PF, Zheng Z, Dudley ME, Feldman SA, Yang JC, Sherry RM, Phan GQ, Hughes MS, Kammula US, Miller AD, Hessman CJ, Stewart AA, Restifo NP, Quezado MM, Alimchandani M, Rosenberg AZ, Nath A, Wang T, Bielekova B, Wuest SC, Akula N, McMahon FJ, Wilde S, Mosetter B, Schendel DJ, Laurencot CM, Rosenberg SA. Cancer Regression and Neurological Toxicity Following Anti-MAGE-A3 TCR Gene Therapy. J Immunother 2013;36:133-51.

185.Davila ML, Sauter C, Brentjens R. CD19-Targeted T Cells for Hematologic Malignancies Clinical Experience to Date. Cancer J 2015;21:470-4.

186. Russell SJ, Peng KW, Bell JC. Oncolytic virotherapy. Nat Biotechnol 2012;30:658-70.

187. Alvarez-Breckenridge C, Kaur B, Chiocca EA. Pharmacologic and Chemical Adjuvants in Tumor Virotherapy. Chem Rev 2009;109:3125-40.

188. Fulci G, Breymann L, Gianni D, Kurozomi K, Rhee SS, Yu JH, Kaur B, Louis DN, Weissleder R, Caligiuri MA, Chiocca EA. Cyclophosphamide enhances glioma virotherapy by inhibiting innate immune responses. Proc Natl Acad Sci U S A 2006;103:12873-8.

Cite this article as: Fang $\mathrm{T}$, Xiao J, Zhang $\mathrm{Y}, \mathrm{Hu} \mathrm{H}$, Zhu Y, Cheng Y. Combined with interventional therapy, immunotherapy can create a new outlook for tumor treatment. Quant Imaging Med Surg 2021;11(6):2837-2860. doi: 10.21037/ qims-20-173
189.Park CG, Hartl CA, Schmid D, Carmona EM, Kim HJ, Goldberg MS. Extended release of perioperative immunotherapy prevents tumor recurrence and eliminates metastases. Sci Transl Med 2018;10:eaar1916.

190.Jung BK, Oh E, Hong J, Lee Y, Park KD, Yun CO. A hydrogel matrix prolongs persistence and promotes specific localization of an oncolytic adenovirus in a tumor by restricting nonspecific shedding and an antiviral immune response. Biomaterials 2017;147:26-38.

191. Mushtaq MU, Papadas A, Pagenkopf A, Flietner E, Morrow Z, Chaudhary SG, Asimakopoulos F. Tumor matrix remodeling and novel immunotherapies: the promise of matrix-derived immune biomarkers. J Immunother Cancer 2018;6:65.

192.Jiang Z, Liu Z, Li M, Chen C, Wang X. Increased glycolysis correlates with elevated immune activity in tumor immune microenvironment. EBioMedicine 2019;42:431-42.

193.Mami-Chouaib F, Blanc C, Corgnac S, Hans S, Malenica I, Granier C, Tihy I, Tartour E. Resident memory T cells, critical components in tumor immunology. J Immunother Cancer 2018;6:87.

194. Marabelle A, Le DT, Ascierto PA, Di Giacomo AM, De Jesus-Acosta A, Delord JP, Geva R, Gottfried M, Penel N, Hansen AR, Piha-Paul SA, Doi T, Gao B, Chung HC, Lopez-Martin J, Bang YJ, Frommer RS, Shah M, Ghori R, Joe AK, Pruitt SK, Diaz LA Jr. Efficacy of Pembrolizumab in Patients With Noncolorectal High Microsatellite Instability/Mismatch Repair-Deficient Cancer: Results From the Phase II KEYNOTE-158 Study. J Clin Oncol 2020;38:1-10. 